INTER NATIONAL MONETARY FUND

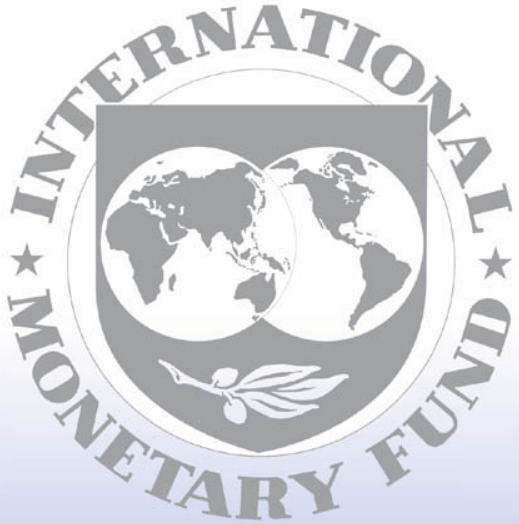

Staff

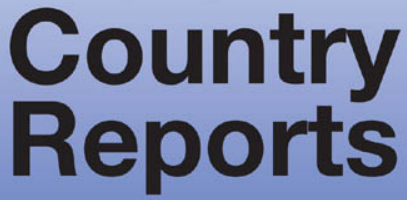




\section{Iceland: 2006 Article IV Consultation-Staff Report; Staff Statement; and Public Information Notice on the Executive Board Discussion}

Under Article IV of the IMF's Articles of Agreement, the IMF holds bilateral discussions with members, usually every year. In the context of the 2006 Article IV consultation with Iceland, the following documents have been released and are included in this package:

- the staff report for the 2006 Article IV consultation, prepared by a staff team of the IMF, following discussions that ended on May 15, 2006, with the officials of Iceland on economic developments and policies. Based on information available at the time of these discussions, the staff report was completed on July 13, 2006. The views expressed in the staff report are those of the staff team and do not necessarily reflect the views of the Executive Board of the IMF.

- a staff statement of August 3, 2006 updating information on recent developments.

- $\quad$ a Public Information Notice (PIN) summarizing the views of the Executive Board as expressed during its August 4, 2006 discussion of the staff report that concluded the Article IV consultation.

The document listed below has been or will be separately released.

Selected Issues Paper

The policy of publication of staff reports and other documents allows for the deletion of market-sensitive information.

To assist the IMF in evaluating the publication policy, reader comments are invited and may be sent by e-mail to publicationpolicy@imf.org.

Copies of this report are available to the public from

International Monetary Fund • Publication Services

$70019^{\text {th }}$ Street, N.W. • Washington, D.C. 20431

Telephone: (202) 623-7430 • Telefax: (202) 623-7201

E-mail: publications@imf.org •Internet: http://www.imf.org

Price: $\$ 15.00$ a copy

\section{International Monetary Fund}

Washington, D.C. 
This page intentionally left blank

CInternational Monetary Fund. Not for Redistribution 


\section{INTERNATIONAL MONETARY FUND}

\section{ICELAND}

\section{Staff Report for the 2006 Article IV Consultation}

Prepared by the Staff Representatives for the 2006 Consultation with Iceland Approved by Alessandro Leipold and Carlo Cottarelli

July 13, 2006

- $\quad$ The Article IV consultation discussions were held in Reykjavik during May 8-15, 2006. The mission team comprised Mr. Hunt (head), Ms. Honjo, Mr. Tchaidze (all EUR) and Ms. Mitra (MFD). Mr. Sigurgeirsson (Alternate Executive Director) attended some of the meetings. The staff met with the Prime Minister, the Minister of Foreign Affairs, the Permanent Secretary in the Prime Minister's Office, the Governor of the Central Bank of Iceland, other senior officials from a wide range of public institutions, the major banks, and employer and employee federations.

- Iceland has accepted the obligations of Article VIII, Sections 2, 3, and 4. The exchange rate is free of restrictions on payments and transfers for current international transactions (Appendix I) other than restrictions notified to the Fund in accordance with Decision No. 144-(52/51).

- The authorities published the mission's concluding statement and intend to publish the staff report.

- $\quad$ Following the poor showing of his Progressive Party (PP) in municipal elections, Prime Minister Halldor Asgrimsson announced his resignation in early June. The Independence Party's (IP) Geir Haarde, formerly the Foreign Minister, took over as Prime Minister and leader of the IP-PP coalition. Mr. Haarde was Minister of Finance from 1998 to 2005.

- $\quad$ There will be a general election in May 2007. 


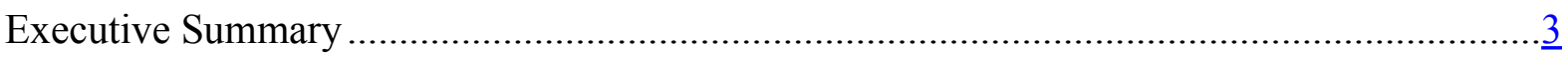

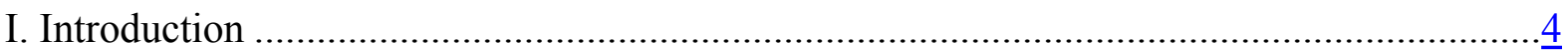

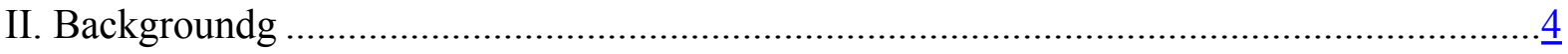

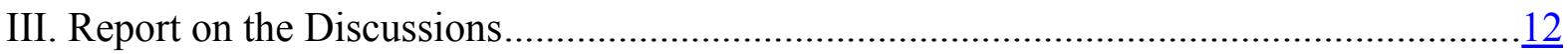

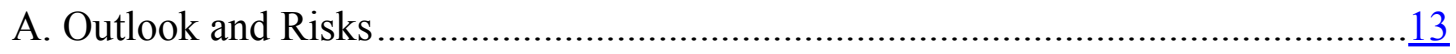

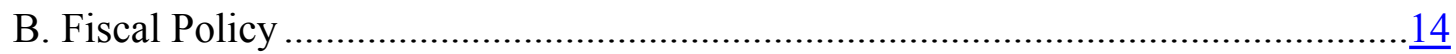

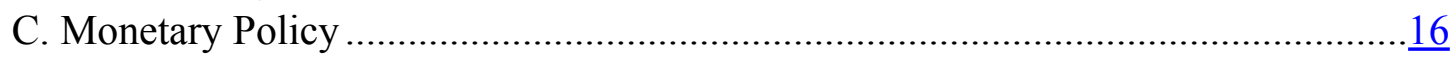

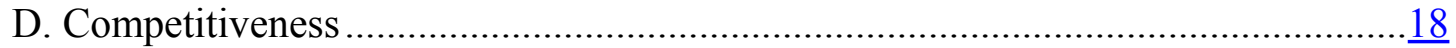

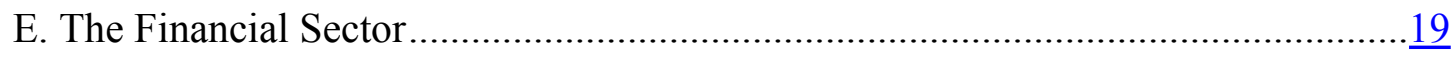

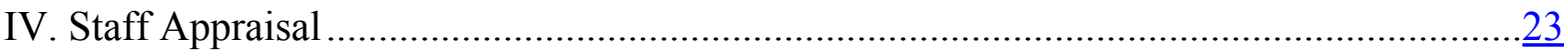

Tables

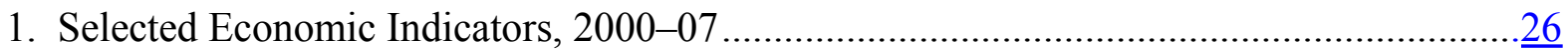

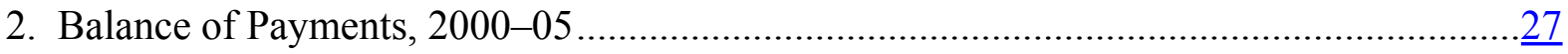

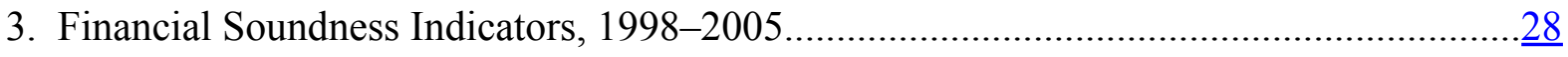

4. Summary Operations of the General Government, 2002-07..........................................

5. Medium-term Scenario, 2003-11 …………….......................................................

Figures

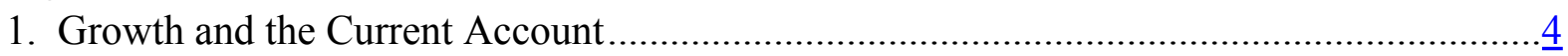

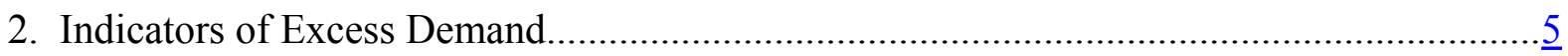

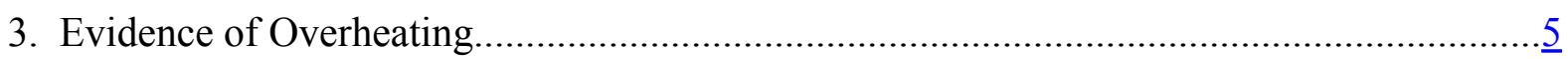

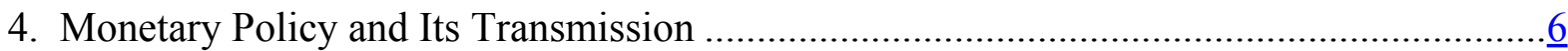

5. Recent Developments in Financial Markets ………..................................................... 1

6. Banking Sector Indicators and Foreign Liabilites ……..............................................

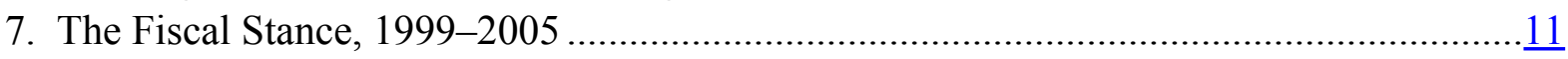

Boxes

1. Icelandic Financial Markets in a Global Context ………...............................................

2. Icelandic Banks' Foreign Expansion and its Impact on their Risk Profile1 …..................... $\underline{9}$

3. Implementation of Past Fund Policy Advice ...............................................................

4. Rules-based Fiscal Policy and Inflation and Output Variability in Iceland..........................16

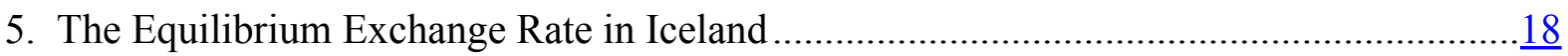

6. Assessment of the Risks in the Icelandic Banking Sector ............................................20

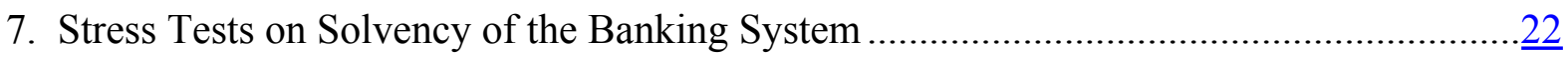

Appendixes

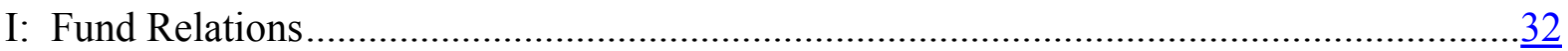

II: External Debt Sustainability .................................................................................. 


\section{Background}

\section{EXECUTIVE SUMMARY}

An economic boom initiated by expansion in the aluminum sector has generated large and growing imbalances in the current account, aggregate demand, and inflation. During the upswing, the balance sheets of Icelandic banks grew notably. Early in the year, international markets became concerned that the macro imbalances and the rapid pace of banks' growth had generated vulnerabilities that could threaten financial stability should the imbalances unwind sharply. Both monetary and fiscal policy have been tightening, but monetary policy has done the largest share.

\section{Key policy issues}

Outlook and Risks: Growth is forecast to remain robust and imbalances persist for the remainder of 2006, but moderate in 2007. Domestic demand is projected to remain the driver of growth generating a still large current account deficit in 2006. However, imbalances are expected to moderate in 2007 with investment returning to a normal level and private consumption contracting. Inflation is forecast to remain well above the $2 \frac{1}{2}$ percent target over the next year and a half. Views differ regarding the risks to the outlook, with staff and the central bank concerned that in the absence of decisive and coordinated policy actions, financial market turbulence could lead to a sharp and severe downturn. The fiscal authorities, however, saw this risk as low, given their view that market turbulence early in the year reflected a temporary misreading of Iceland's fundamentals.

Fiscal policy: Given concerns over the resolution of imbalances and the associated impact on the real economy and the financial sector, staff see a strong case for a tighter-than-budgeted fiscal stance in 2006 and, if warranted, in 2007. The authorities perceive less need to take urgent fiscal action in 2006, but see some scope for tightening in 2007 should the economy not cool as required.

Monetary policy: There is consensus that the policy rate will need to rise further to contain expectations and return inflation to target. Expeditious reform of the state-owned Housing Financing Fund is viewed by all to be essential to increase the effectiveness of monetary policy, though staff consider the initial proposal to fall short of what will be required.

Financial sector: Although traditional indicators of financial sector health suggest the banks remain sound, the rapid expansion of their balance sheets has increased key risks in liquidity, credit, and interconnectedness through crossholdings of equity. However, banks have taken considerable steps to ensure their liquidity requirements are met; credit quality has remained high; and crossholdings of equity are being reduced. This notwithstanding, the process needs to continue to further reduce risks. 


\section{INTRODUCTION}

1. An economic boom initiated by expansion in the aluminum sector has generated large and growing imbalances. During the upswing, the current account deficit widened appreciably and the balance sheets of Icelandic banks grew tremendously. Early in the year, international markets became concerned that the macro imbalances and the rapid pace of banks' growth had generated vulnerabilities that could threaten financial stability should the imbalances unwind sharply.

\section{BACKGROUND}

\section{Over the last three years, a rapid expansion in domestic demand has} dramatically widened the current account deficit (Tables 1-2, Figure 1). Following a 3 percent increase in 2003, GDP growth jumped to 8.2 percent in 2004, and slowed only modestly to $5 \frac{1}{2}$ percent in 2005 . With the expansion being stimulated by new investment projects in the aluminum sector, a rapid pickup in investment was expected. However, the response of consumption surprised on the upside. The stimulus to household income and confidence was amplified by income tax cuts and increased competition in the mortgage market. The current account deficit reached $16 \frac{1}{2}$ percent of GDP in 2005 , double the initial forecast, with the bulk of the surprise reflecting increased imports of consumption goods. Roughly one-third of the deficit reflects the new investment projects.

Figure 1. Growth and the Current Account
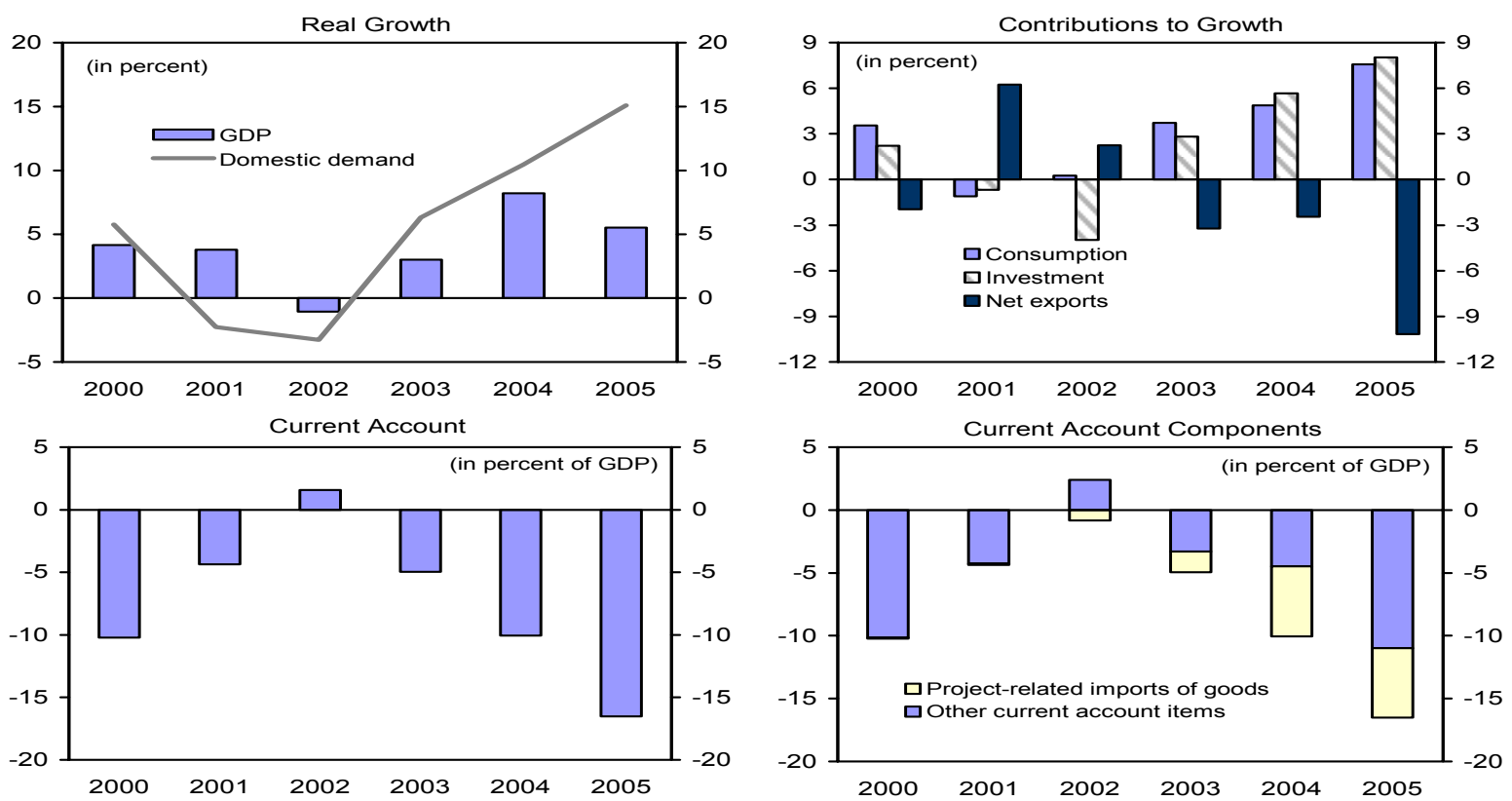


\section{Demand expanded faster than supply and evidence of overheating is widespread}

(Figures 2-3). Staff estimate a positive output gap of over 4 percent in 2005, larger than the

Figure 2. Indicators of Excess Demand
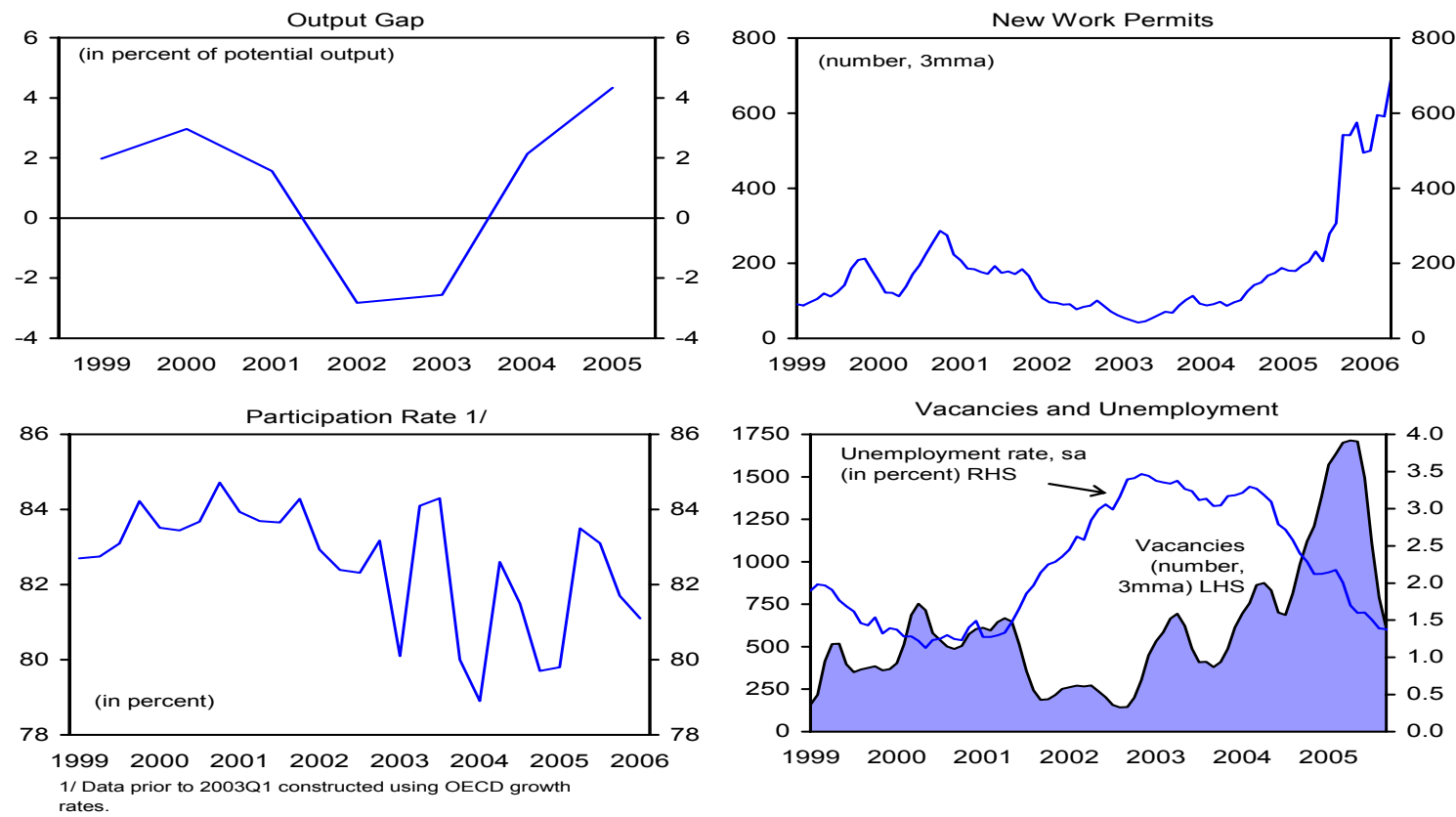

Figure 3. Evidence of Overheating
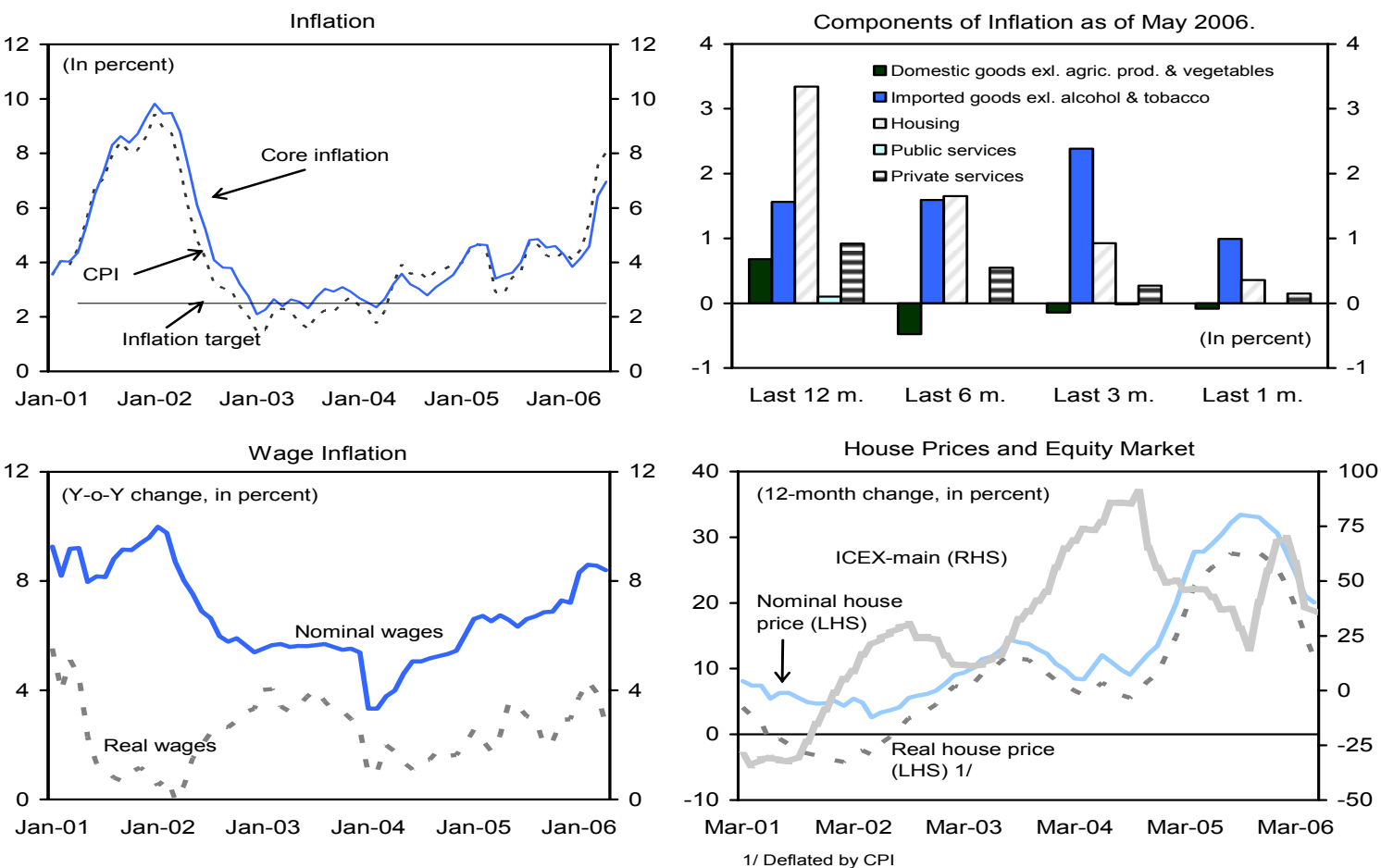
estimated peak in the late 1990s. During this upswing, temporary work visas have made it easier for firms to utilize imported labor and labor market participation remained strong. However, this has not prevented the unemployment rate from falling below $1 \frac{1}{2}$ percent, and reported vacancies remain high. CPI inflation has been persistently above the central bank's 4 percent upper tolerance limit. Inflation has been driven by house price rises that more than offset the effect of earlier currency appreciation and rapid increases in service prices. In light of labor productivity developments, wage inflation of over 8 percent is well above the rate consistent with the central bank's inflation target. Limited pass-through of exchange rate appreciation into import prices over the last half of 2005 suggests that pressures on capacity are high. Equity prices rose more than 50 percent in each of the last three years.

\section{Monetary policy has tightened, but, until recently, the impact has been} channeled primarily through the exchange rate (Figure 4). In response to growing inflationary pressures, the policy rate was increased from 5.3 percent in May 2004 to $12 \frac{1}{4}$ percent at end-June 2006. However, households and firms have not felt the full impact of the tightening and bank credit growth has accelerated. Benign conditions in global financial markets enabled some firms to borrow at low foreign rates, and real mortgage rates declined. Also, through early February, the currency appreciated in response to interest rate spreads, focusing the impact of the tightening on the export sector. However, the market turbulence that set in thereafter has led effective lending rates to better reflect the policy rate.

Figure 4. Monetary Policy and Its Transmission
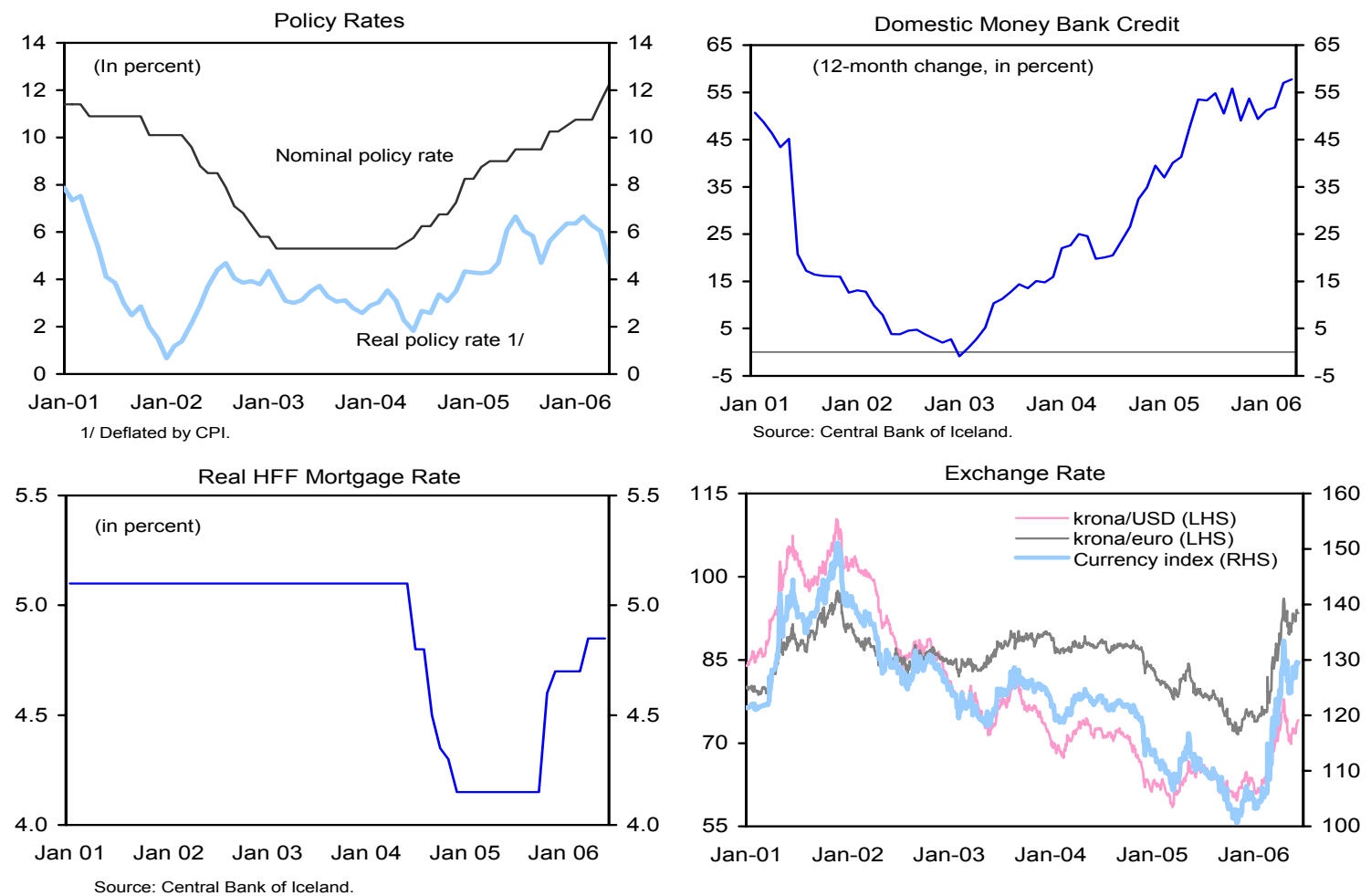
5. Despite hikes in the policy rate, increased competition in the mortgage market eased household credit conditions, and household indebtedness has surged. In July 2004, the publicly owned Housing Finance Fund (HFF), designed to provide equal access to mortgage financing throughout the country, changed the way it funded and priced mortgage loans. This change lowered rates to households and prompted domestic banks to aggressively enter the market. Banks offered comparable rates, higher loan-to-value ratios, and allowed the refinancing of existing mortgages, giving households newfound access to built-up home equity. Household debt is now more than double the level of

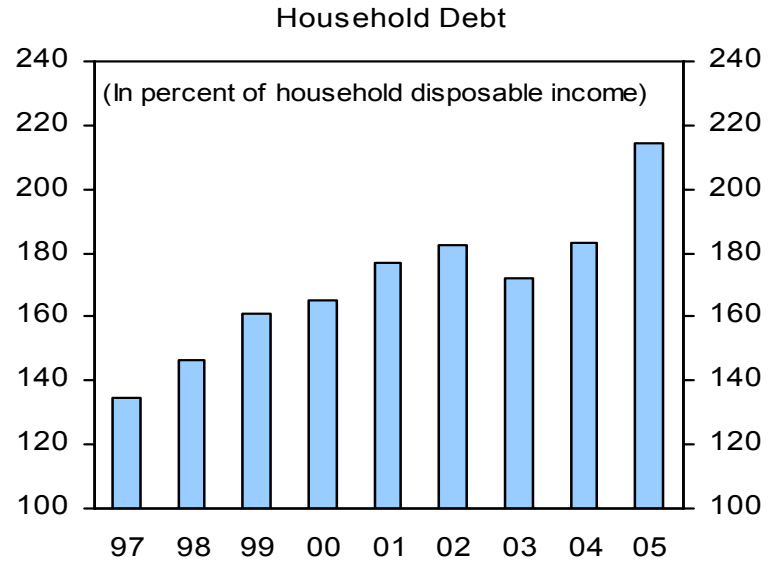
disposable income.

\section{Against the background of accumulating imbalances, a series of negative reports} from ratings agencies and analysts stoked market concerns early this year (Figure 5). In mid-February, a report from Fitch Ratings changed the outlook on sovereign debt from stable to negative, citing concerns over widening macro imbalances and vulnerabilities in the highly leveraged financial sector. Some additional negative reports followed, heightening the sensitivity to loss among leveraged investors (global carry trades) as global monetary policy conditions tightened (Box 1). Consequently, the exchange rate depreciated, the equity market declined, banks' bond prices fell, and spreads widened — all by appreciable amounts.

Figure 5. Recent Developments in Financial Markets
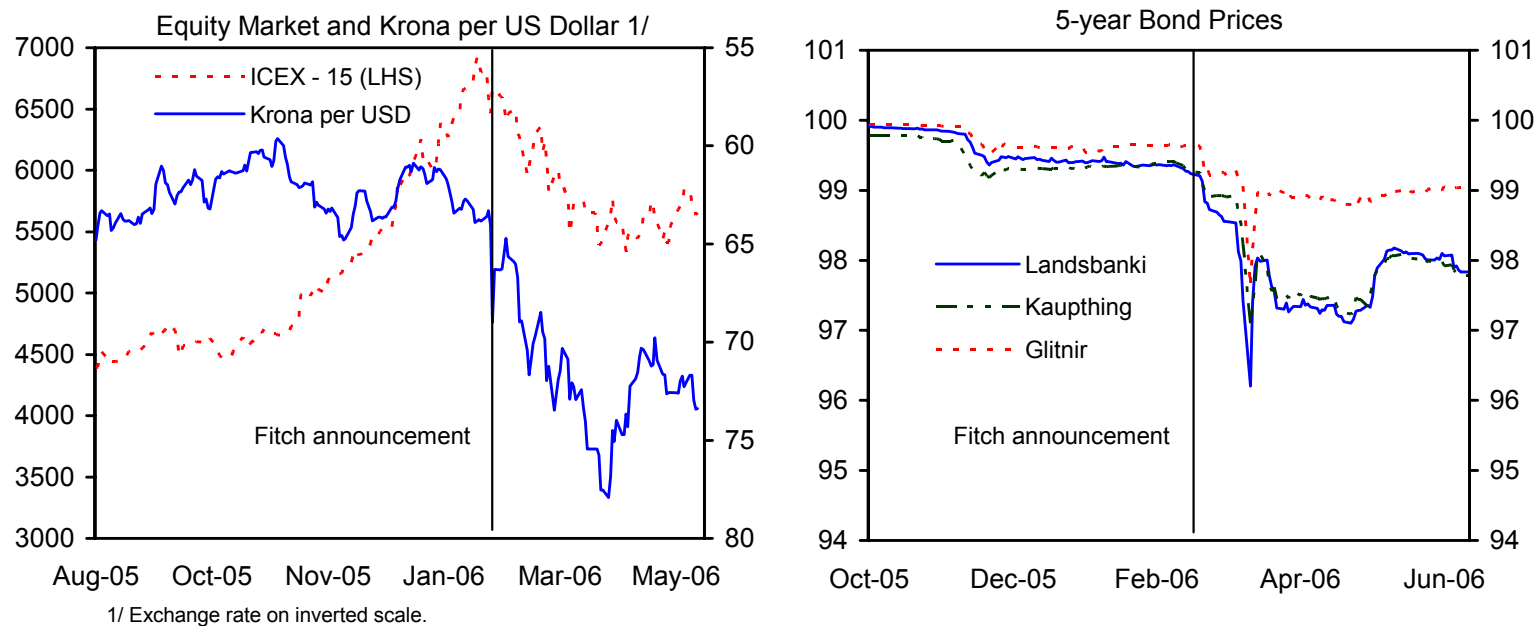


\section{Box 1. Icelandic Financial Markets in a Global Context}

In the first half of 2006, financial market participants became increasingly concerned about several countries with high-yielding currencies, at times citing their external positions as worrisome. Countries frequently mentioned by analysts include Iceland, New Zealand, Turkey, Brazil, and Indonesia. The timing of movements across countries suggests that Iceland and New Zealand may have simply been the first countries to feel the impact of those concerns, possibly reflecting their large external imbalances. In Iceland and New Zealand the depreciations and stock market declines started in February. However, in Turkey, Brazil and Indonesia, they occurred mostly in May, in the context of a broader re-assessment of vulnerabilities and asset valuations in emerging market.

\begin{tabular}{|c|c|c|c|c|c|c|c|}
\hline \multicolumn{2}{|c|}{2005 Current Account } & \multicolumn{3}{|c|}{$\begin{array}{c}\text { Currency depreciation } \\
\text { since Jan } 2 \text { till trough of ... }\end{array}$} & \multicolumn{3}{|c|}{$\begin{array}{c}\text { Equity market decline } \\
\text { since peak of ... till June } 27\end{array}$} \\
\hline Iceland & $-16.5 \%$ & Iceland & 21-Apr & $23.4 \%$ & Iceland & $15-\mathrm{Feb}$ & $19.8 \%$ \\
\hline New Zealand & $-8.8 \%$ & New Zealand & 29-Mar & $11.8 \%$ & New Zealand & 7-Apr & $4.9 \%$ \\
\hline Turkey & $-6.4 \%$ & Turkey & 22-Jun & $17.9 \%$ & Turkey & 27-Feb & $32.0 \%$ \\
\hline Indonesia & $0.3 \%$ & Indonesia & n.a. & n.a. & Indonesia & 11-May & $17.2 \%$ \\
\hline Brazil & $1.8 \%$ & Brazil & 24-May & $1.5 \%$ & Brazil & 9-May & $16.7 \%$ \\
\hline
\end{tabular}
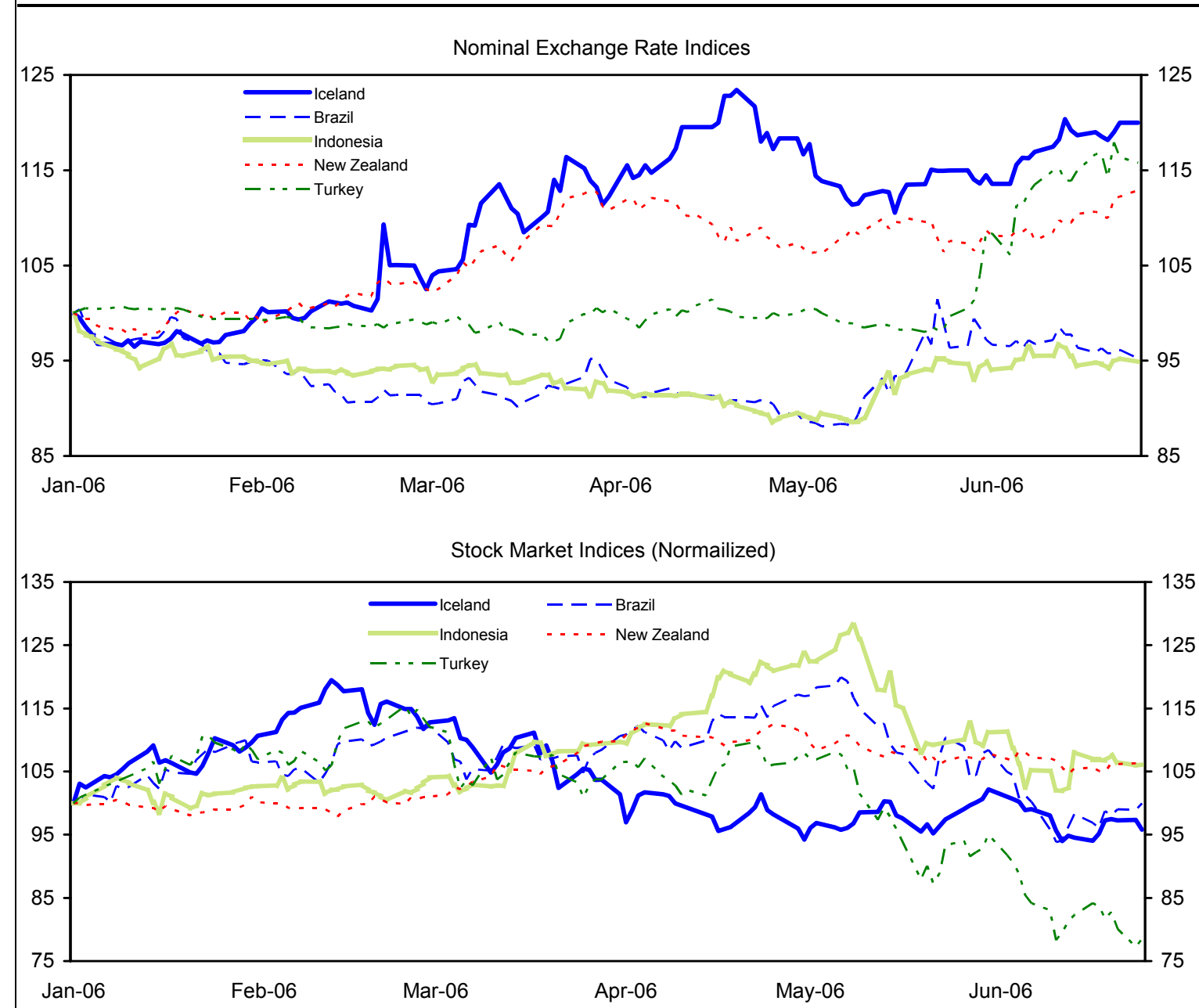

Sources: Bloomberg and Datastream. 


\section{The financial market turbulence early in the year ended the favorable conditions} that had allowed banks to fund rapid balance sheet growth (Figure 6 and Table 3). High levels of capitalization, strong profitability, and low default rates resulted in high credit ratings for Icelandic banks. With benign global financial market conditions, banks were able to significantly increase foreign liabilities, with a large portion reflecting banks' acquisition of financial firms in Europe. Although this expansion diversified banks' income streams,concerns about the resolution of Iceland's imbalances and tightening global credit conditions raised doubts about banks' near-term prospects (Box 2). In particular, concerns centered on their ability to refinance liabilities falling due over the remainder of 2006 and 2007.

\section{Box 2. Icelandic Banks' Foreign Expansion and its Impact on their Risk Profile ${ }^{1}$}

The rapid foreign expansion of Icelandic banks in 2004-05 diversified revenues and added deposit base. Banks achieved record profitability in 2006Q1, despite the financial turmoil, partly due to foreign subsidiaries' performance.

Geographic Diversification of Loan-book and Revenues in 2005 (in percent) 1/

\begin{tabular}{|c|c|c|c|c|c|c|}
\hline & \multicolumn{2}{|c|}{ Glitnir } & \multicolumn{2}{|c|}{ Landsbanki } & \multicolumn{2}{|c|}{ Kaupthing } \\
\hline & Revenue & $\begin{array}{c}\text { Loan book } \\
\text { exposure }\end{array}$ & Revenue & $\begin{array}{c}\text { Loan book } \\
\text { exposure }\end{array}$ & Revenue & $\begin{array}{c}\text { Loan book } \\
\text { exposure }\end{array}$ \\
\hline Iceland & 71 & 45 & 83 & 67 & 30 & 23 \\
\hline Scandinavia & 13 & 43 & 0 & 0 & 26 & 40 \\
\hline United Kingdom & 3 & 7 & 11 & 14 & 34 & 25 \\
\hline Other & 13 & 5 & 6 & 19 & 10 & 12 \\
\hline Total & 100 & 100 & 100 & 100 & 100 & 100 \\
\hline
\end{tabular}

Source: Banks' Annual Financial Statements, Morgan Stanley.

1/ Loan book exposure for Kaupthing as of 2005Q3.

But risks have also increased. First, banks' reliance on wholesale funding has increased considerably owing to some foreign acquisitions that are wholesale-funded, increasing banks' refinancing risks. Second, integrating newly acquired businesses could be challenging in a lesser known environment, which complicates managing credit risk and market risks.

To mitigate such risks, the Financial Supervisory Authority (FME) has signed Memoranda of Understanding with host supervisors to enhance cooperation and information sharing. Moreover, the FME has also conducted onsite supervision in select subsidiaries. Based on FSAP recommendations, the FME now requires banks to report on their policies and procedures for identifying and controlling country risk in their international lending and investments.

\footnotetext{
${ }^{1}$ Selected Issues Paper "Risks and Vulnerabilities in Icelandic Banks."
} 
Figure 6. Banking Sector Indicators and Foreign Liabilities
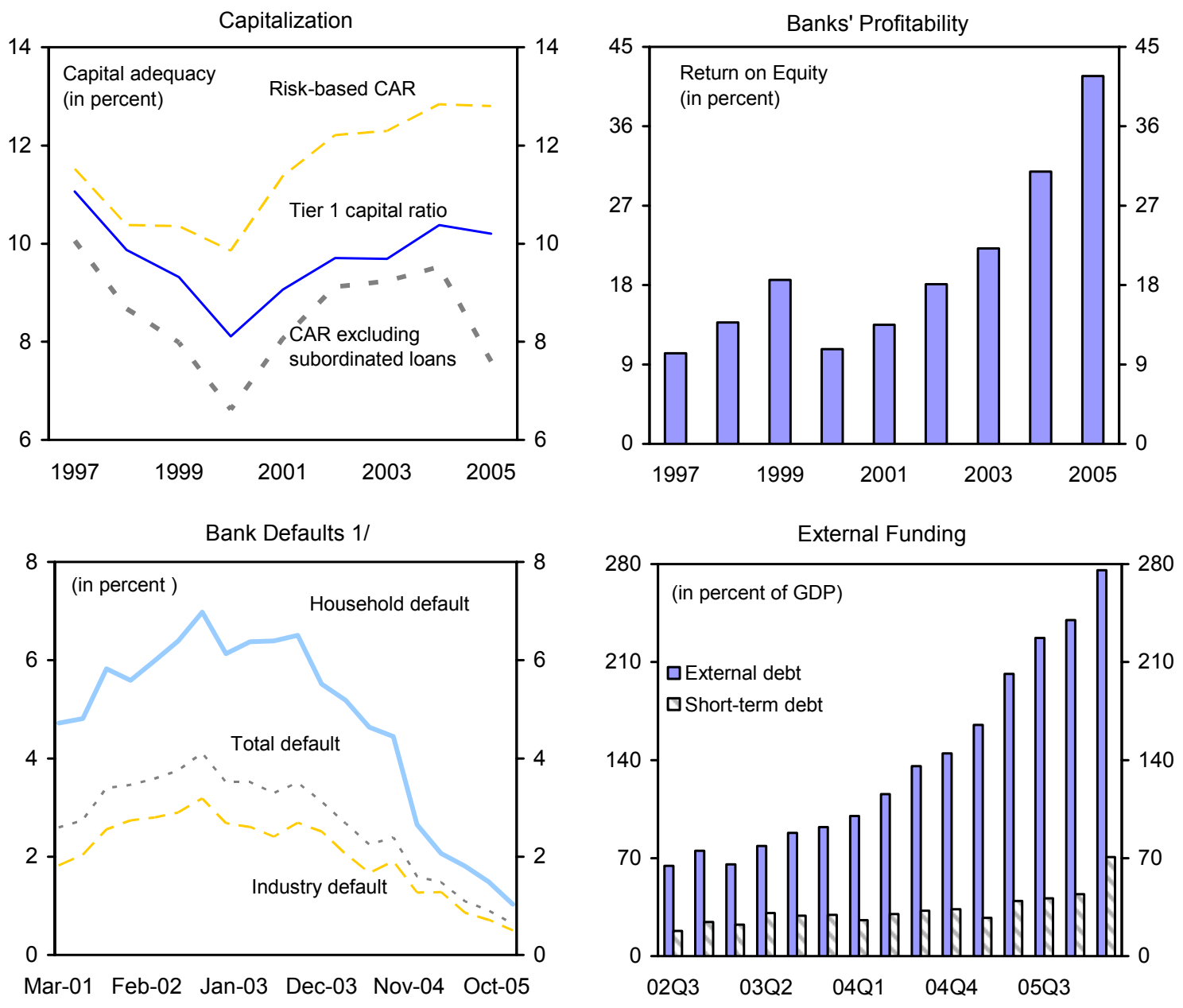

Net External Debt: Banks 1/
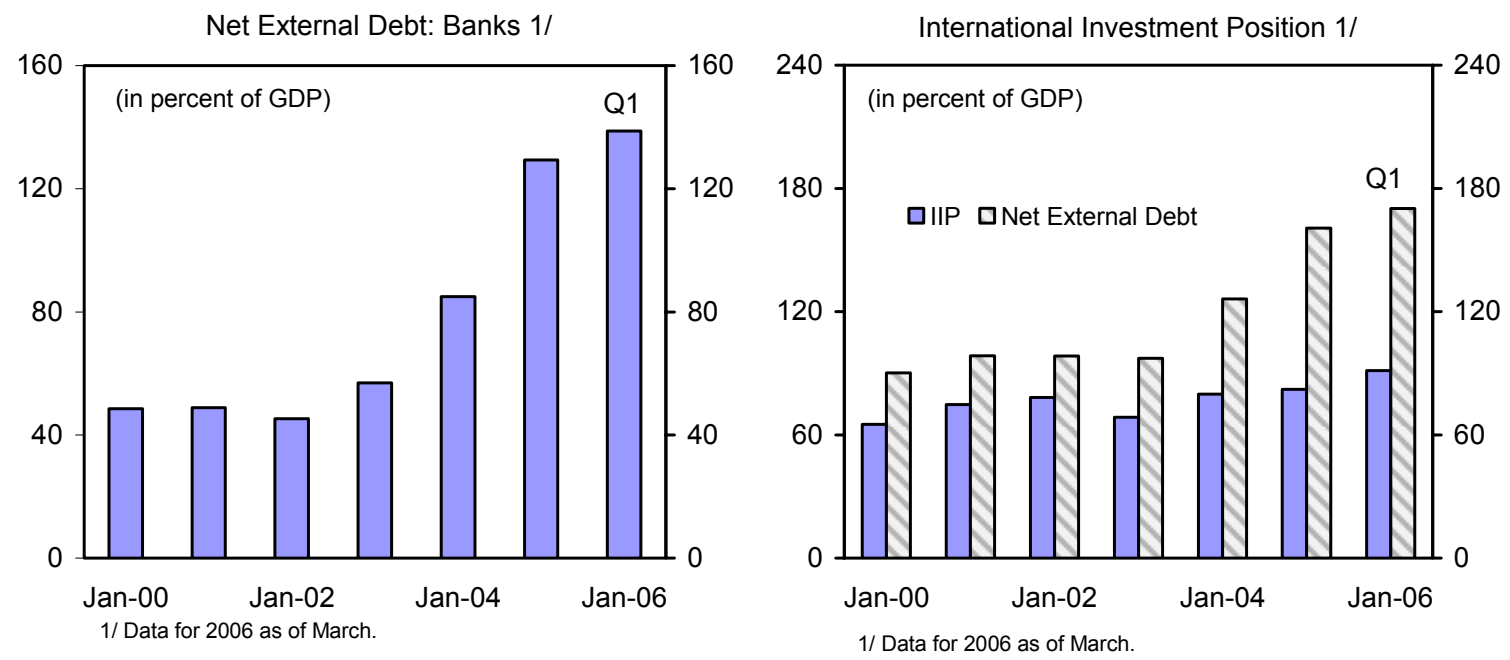

Sources: Bloomberg, Central Bank of Iceland, FME, and Statistics Iceland.

$1 /$ As a percent of appropriate loan category. 
8. Fiscal policy was tightened in $\mathbf{2 0 0 5}$, but remained less restrictive than during the last cycle (Figure 7 and Table 4). The general government balance moved from a deficit of almost 2 percent of GDP in 2003 to a surplus of roughly 3 percent of GDP in 2005.

Approximately half of the 2005 surplus reflects unexpectedly higher tax receipts, buoyed by the consumption and housing market booms. In cyclically-adjusted terms, a deficit of 1 percent of GDP in 2004 swung to a surplus of roughly 1 percent of GDP in 2005. However, given the magnitude of the cycle, fiscal policy has not been as restrictive in level terms as it was in the previous cycle because of income tax cuts and nominal public consumption growth in excess of 8 percent in 2005.

Figure 7. The Fiscal Stance, 1999-2005
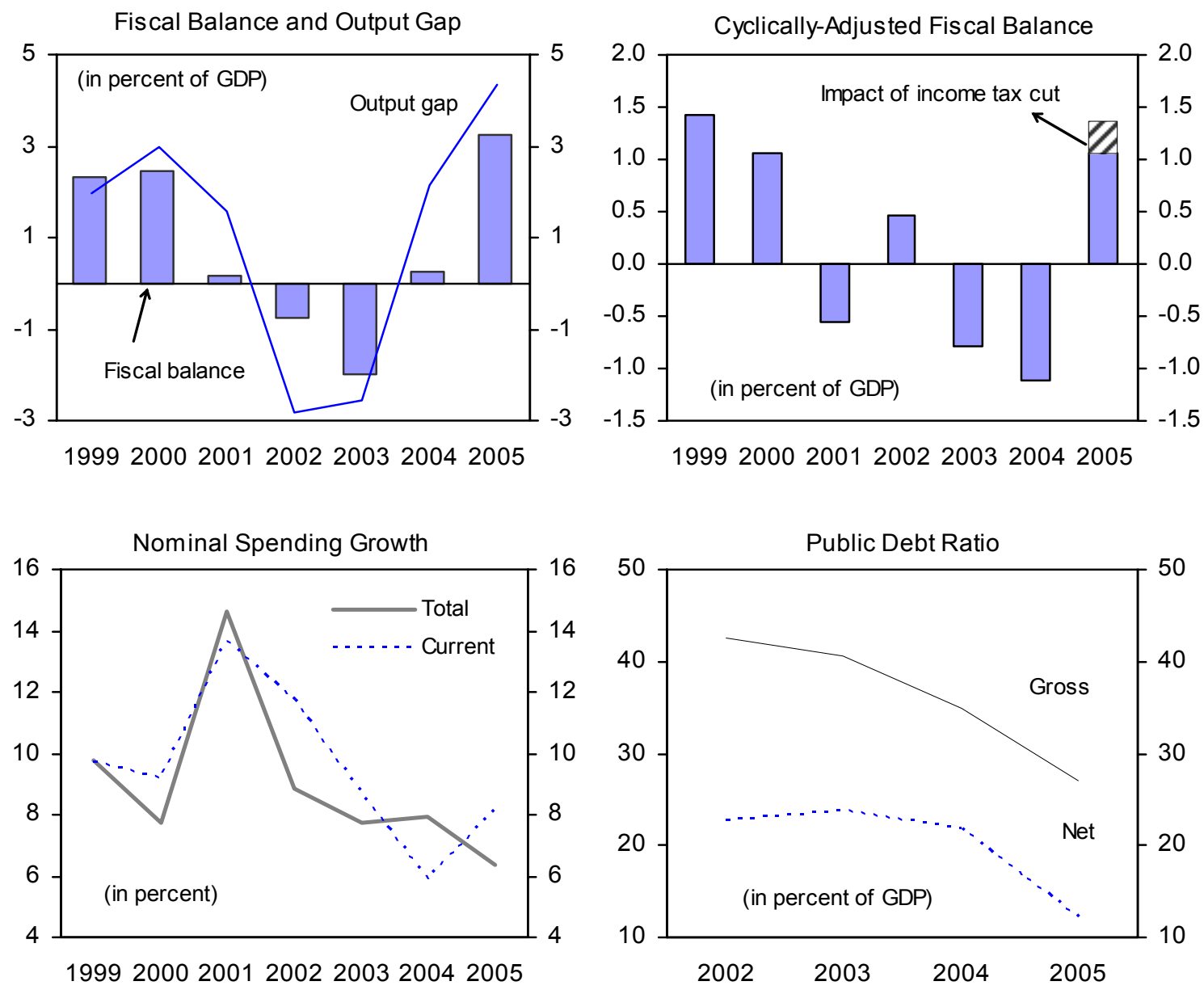


\section{Box 3. Implementation of Past Fund Policy Advice}

The authorities have generally pursued policies consistent with Fund advice in structural, financial, and monetary policy areas. There has been, however, more resistance to Fund advice on fiscal policy.

The 2001 Financial Sector Assessment Program (FSAP) served as the basis for strengthening the financial supervisory legal framework and established standards for controlling and managing risk in the payments system. Following the 2005 consultation, the central bank introduced changes to its communication strategy and the Financial Supervisory Authority increased the breadth and stringency of its stress tests, both consistent with Fund advice.

On fiscal policy, introducing multi-year spending targets into the budget was consistent with Fund advice on strengthening the fiscal framework. However, there has been considerably less agreement with the advice on the appropriate cyclical fiscal stance. Further, the authorities have been reluctant to follow Fund advice on reforming the state-owned HFF, the largest mortgage lending institution in Iceland. The HFF reform process has only recently been initiated.

\section{REPORT ON THE DISCUSSIONS}

9. Given concerns over the resolution of imbalances and the associated impact on the real economy and the financial sector, discussions focused on the policies to help ensure a soft landing and financial stability. There was agreement that the increased flexibility and sound structural fundamentals of the Icelandic economy were aspects that stood to aid the benign resolution of the current imbalances. However, staff stressed that the heightened level of concern in financial markets and the real costs associated with a hard landing made it imperative that policy actions be taken to stabilize confidence, and help ensure an orderly adjustment and maintain financial stability. Accordingly, discussions focused selectively on the following imperative policy priorities:

- the needed contribution of fiscal restraint, and in particular, the prospects for achieving a tighter-than-budgeted fiscal stance in 2006 and, if warranted, beyond;

- $\quad$ the path for the policy interest rate required to return inflation to target without a larger than necessary slowing in economic activity; and

- the authorities' role in strengthening the financial sector and ensuring speedy reform of the HFF.

10. Although there was broad agreement in many areas, there were key differences between staff and fiscal authorities who saw less need for a tightening in fiscal policy. The official view on fiscal policy reflected a lower estimate of excess demand, constraints on implementing a tighter stance, and a perception that the market turbulence early in the year was driven by misinformation that had subsequently been corrected. 


\section{A. Outlook and Risks}

11. In both the authorities' and staff's baseline projection, growth is likely to remain robust and imbalances persist for the remainder of 2006, but moderate in 2007

(Table 5). GDP growth is expected to be in the range of 4 to 5 percent in 2006 and 1 to 2 percent in 2007. The completion of the aluminum sector projects and continued strong private consumption are seen to be the drivers of growth in 2006. Accordingly, despite some improvement, the strength in domestic demand is projected to generate a still large current account deficit in 2006 (12 $\frac{1}{2}$ percent of GDP versus 16 $1 / 2$ percent of GDP in 2005). However, with investment returning to a normal level and private consumption contracting due to exchange rate depreciation and tightening credit conditions, domestic demand is projected to fall in 2007, cutting the current account deficit by more than half. In 2007, export growth due to increased aluminum production and a more favorable exchange rate is forecast to rebalance growth and contribute to the improvement in the current account.

Iceland: Current Account, 2005-07

(in percent of GDP)

\begin{tabular}{|c|c|c|c|}
\hline & $\begin{array}{l}2005 \\
\text { Act. }\end{array}$ & $\begin{array}{l}2006 \\
\text { IMF }\end{array}$ & $\begin{array}{l}2007 \\
\text { IMF }\end{array}$ \\
\hline Current Account & -16.5 & -12.5 & -4.4 \\
\hline Balance on Goods & -9.3 & -5.1 & 3.2 \\
\hline Exports of goods & 19.6 & 24.2 & 27.5 \\
\hline Imports of goods & -28.9 & -29.3 & -24.3 \\
\hline o/w project-related & -5.5 & -1.6 & -0.6 \\
\hline Balance on Services & -3.4 & -2.4 & -2.2 \\
\hline Balance on Income & -3.5 & -4.9 & -5.3 \\
\hline Current transfers, net & -0.2 & -0.1 & -0.1 \\
\hline
\end{tabular}

Source: Central Bank of Iceland and staff forecasts.

\section{Although there was broad agreement that inflation would remain above the} central bank's target over the next year and a half, the fiscal authorities forecast less persistence. Staff and the central bank see exchange rate depreciation, and pressures in goods and labor markets keeping CPI inflation well above the $2 \frac{1}{2} 2$ percent target. However, reflecting different assumptions about how quickly aluminum sector investment should be added to productive capital, ${ }^{1}$ the fiscal authorities estimate less excess demand. In addition, they saw less pressure on wages, assuming a more favorable outcome to the potential revisiting of the wage agreement in November ${ }^{2}$ and expecting labor market pressures to ease

\footnotetext{
${ }^{1}$ The fiscal authorities immediately add investment flows to productive capital whereas staff add investment flows to the capital stock only after the associated plant and equipment has become fully productive.

2 The multi-year wage agreement contains the provision to revisit previously agreed wage increases should inflation persistently exceed the central bank's 4 percent upper tolerance limit, as is the case this year. At the end of June, the social partners agreed to keep the wage agreement in force given the government's commitment to change to the personal exemption for income tax. The change will be financed by reducing the 2007 cut in the income tax rate from 2 percentage points to 1 percentage point.
} 
following the opening of the labor market to the new EU member states on May 1, 2006. Most of the mission's stakeholders projected that house price appreciation, which until recently had been the key driver of inflation, would moderate as mortgage credit conditions tighten and housing supply increases. Few saw a significant risk of house price declines.

13. There were notable differences in views regarding the risks to the outlook. In the absence of decisive and coordinated policy actions that cool the economy and re-anchor confidence, staff saw significant risks that further financial market turbulence could lead to a sharp and severe downturn, a concern shared by the central bank. While in an uncertain environment various scenarios are possible, the main concern was that financial market discomfort, given imbalances and their potential impact on a perceived vulnerable financial sector, could spark tightening in banks' liquidity conditions and rapid currency depreciation. This in turn could force the banks to curtail domestic credit growth abruptly. Consequently, the contraction in domestic demand could be amplified, with negative implications for incomes and second-round affects on banks. With inflation receiving further stimulus from currency depreciation, the central bank would be forced to sustain tighter monetary conditions longer, resulting in a prolonged period with output below potential. The fiscal authorities, however, saw this risk as low, given their view that market turbulence primarily reflected a temporary misreading of Iceland's fundamentals.

\section{B. Fiscal Policy}

\section{Although some merit was seen in tightening the fiscal stance over the remainder} of 2006, the authorities pointed to several factors that would make it difficult. With imbalances larger than expected at the time of the 2006 budget, staff recommended that additional public investment projects be delayed and growth in public consumption be reduced from the 8.2 percent budgeted. Staff suggested that, at a minimum, the target for the 2006 fiscal surplus as a share of GDP be unchanged from 2005. Although. the authorities perceived less need to take urgent fiscal action, they did note that the strength in the economy would likely deliver stronger revenues, improving the surplus relative to even their most recent forecast. They also pointed

General Government: Options for Measures in 2006 and Conditional Measures for 2007 1/ (in percent of GDP)

\begin{tabular}{lrr}
\hline & 2006 & 2007 \\
\hline Total impact of measures & 1.1 & 1.6 \\
Revenue measures & $\ldots$ & 0.6 \\
Delay reduction in personal income tax & 1.1 & 1.0 \\
Expenditure measures & 0.8 & 0.2 \\
$\quad$ Contain pub. consumption growth to 6.5\% & 0.3 & 0.8 \\
Contain public investment at 2.2\% of GDP & & \\
Overall balance & 2.1 & -0.8 \\
$\quad$ Without measures & 3.2 & 0.9 \\
$\quad$ With measures & & \\
Overall balance (cyclically adjusted) 1/ & 0.3 & -0.5 \\
$\quad$ Without measures & 1.4 & $\ldots$ \\
$\quad$ With measures & & \\
\hline Source: Staff estimates. & & \\
1/ Conditional on stronger grow th in 2007, thus cyclically-adjusted balances are not \\
comparable.
\end{tabular}

to several factors that would make it difficult to reduce 2006 expenditures: limited scope for discretionary adjustment, lags in the planning process, and the political economy setting provided by the upcoming general election. 
Iceland: General Government 2002-07 1/

\begin{tabular}{|c|c|c|c|c|c|c|c|c|}
\hline & \multirow{2}{*}{2002} & \multirow{2}{*}{2003} & \multirow[t]{2}{*}{2004} & \multirow{2}{*}{$\begin{array}{l}2005 \\
\text { Prel. }\end{array}$} & \multicolumn{2}{|c|}{2006} & \multicolumn{2}{|c|}{2007} \\
\hline & & & & & $\mathrm{MoF}$ & $\mathrm{IMF}$ & MoF & IMF \\
\hline Revenue & 45.7 & 46.4 & 47.5 & 49.4 & 46.4 & 46.0 & 44.6 & 44.8 \\
\hline Expenditure & 46.5 & 48.4 & 47.2 & 46.2 & 44.6 & 43.8 & 46.0 & 45.5 \\
\hline Overall balance & -0.8 & -2.0 & 0.3 & 3.2 & 1.8 & 2.1 & -1.5 & -0.8 \\
\hline Structural balance 2/ & 0.5 & -0.7 & -0.8 & 1.1 & $\ldots$ & 0.3 & $\ldots$ & -0.5 \\
\hline Change (+ contractionary & 1.1 & -1.2 & -0.1 & 1.9 & . & -0.7 & $\ldots$ & -0.8 \\
\hline Gross debt & 42.6 & 40.6 & 35.0 & 27.0 & 24.1 & 23.3 & $\ldots$ & 23.1 \\
\hline Net debt & 22.8 & 23.7 & 21.8 & 12.2 & 10.0 & 9.5 & $\ldots$ & 9.3 \\
\hline
\end{tabular}

Source: Ministry of Finance; and staff estimates.

1/ Official forecast of the Ministary of Finance as of Aptil 2006. Staff projections, consistent with Table 4.

2/ In percent of potential GDP, based on staff's estimate of the output gap.

15. The authorities saw some scope for tightening the fiscal stance in 2007. Staff advised that an announcement be made that the 2007 budget would contain measures to reduce aggregate demand should the economy not cool as required. Staff pointed to delaying planned income tax cuts, slowing public consumption growth and reducing the pickup in public investment as possibilities. The authorities noted that the latter possibility was indeed being considered and talks to this end were underway. ${ }^{3}$ While reiterating that the 2007 tax cut would come when domestic demand was expected to be contracting, they noted that the cut could be modified to help avoid an inflationary change to the multi-year wage agreement.

\section{The authorities noted that the fiscal framework had been improved in a number} of ways and did not see much scope for further strengthening in the near term. Building on previous mission work, staff noted how a rules-based fiscal policy delivering a consistently countercyclical fiscal stance could contribute to stabilizing the Icelandic economy (Box 4). Because of the large economic shocks in Iceland, it is more important than in other industrial countries that fiscal policy strongly reinforce monetary policy. The authorities agreed in principle, and argued that the current framework, with multi-year spending targets and countercyclical adjustments to public investment, was a "quasi" fiscal rule. However, they acknowledged that generating the three-year spending targets using the central bank's inflation target rather than their inflation forecast would increase the counter cyclicality of fiscal policy, transparency, and accountability. Nevertheless, because of the strong indexing culture in Iceland, building the political consensus for such a change would take time. However, the authorities expressed interest in working with staff to develop a range of feasible rules-based frameworks.

\footnotetext{
${ }^{3}$ On June 27 the government announced a reduction in public investment in 2007 close the amount suggested by staff. Further, the maximum loans and loan-to-value ratios at the government-owned HFF were also reduced.
} 


\section{Box 4. Rules-based Fiscal Policy and Inflation and Output Variability in Iceland}

Efficient policy frontiers constructed using estimated macroeconomic models suggest that the inflationoutput variability trade-off faced by the monetary authorities in Iceland is considerably less favorable than in other industrial countries. This reflects the relative magnitude of economic disturbances in Iceland.

Systematic coordination of monetary and fiscal policy, however, could help improve the trade-off. The introduction of a simple fiscal rule designed to simultaneously ensure a consistently countercyclical fiscal stance and achieve a stable public debt target shifts the efficient frontier toward the southwest, reducing inflation, output, interest rate, and exchange rate variability. ${ }^{1}$

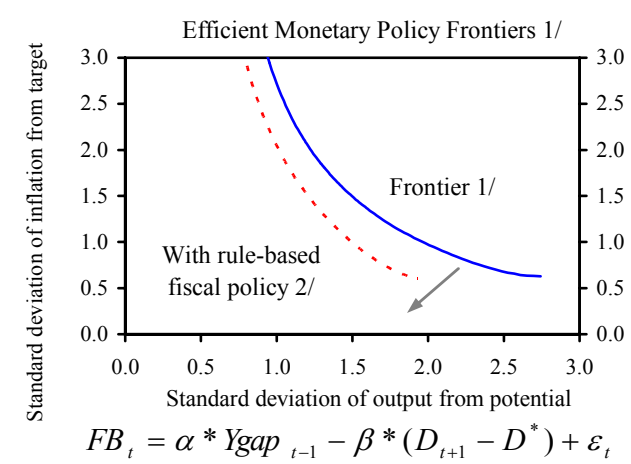

1/ From B. Hunt, "Simple Efficient Policy Rules and Inflation Control in Iceland." (IMF Country Report No.05/366).

2 / Fiscal policy defined as above, where fiscal balance (FB) is determined by a cyclical component (Ygap - output gap) and the debt gap (D-D* - deviation from the debt target).

${ }^{1}$ Selected issues paper "Rules-Based Fiscal Policy and Inflation and Output Variability in Iceland."

\section{Monetary Policy}

\section{The tightening in monetary policy over the last year was jointly viewed as} appropriate, but mortgage market developments had limited its impact on domestic

demand. With inflation persistently above the central bank's 4 percent upper tolerance limit, monetary conditions needed to tighten. However, competition in the mortgage market between the banks and the HFF kept real mortgage rates low and loan conditions easy. Consequently, the increase in the policy rate was prevented from having a significant impact on household credit conditions. There was agreement that reform of the HFF would help restore a more traditional transmission mechanism for monetary policy and thereby improve its effectiveness. However, with predominantly long-term fixed-real-rate mortgages that amortize inflation surprises over the remaining term, the policy rate was likely to be less effective than in other countries having largely shorter-term, nominal-rate mortgage contracts. Nonetheless, it was thought possible that following effective HFF reform, mortgage contracts could evolve to give the policy rate greater impact on household credit conditions. $^{4}$

\footnotetext{
${ }^{4}$ Even in the current market, some banks have introduced mortgages which reset the interest rate every five years.
} 
18. The authorities outlined the initial proposal for reforming the HFF; however, banks expressed strong reservations to which staff were sympathetic. The proposal involved a new state-owned entity that would raise funds, design mortgage products, and control credit approval. Banks would sell these products under their own brands, and bear the credit risk during the initial few years of the mortgage. The banks expressed their desire for the state to withdraw from the mortgage market, wind down the HFF, and create a new privately held wholesale financing entity. Such a system would allow them to retain the mortgages on their balance sheets, design products they felt best suited the market, and retain loan approval authority.

19. There was consensus that the policy rate would need to rise further to contain expectations and return inflation to target over a reasonable horizon. With additional inflationary pressures expected from currency depreciation, and tight goods and labor markets, it was agreed that the central bank needed to act decisively to raise real interest rates and anchor expectations. ISK Euro bonds maturing in the last quarter of the year were anticipated to weaken the currency and there were no strong indicators that demand pressures were starting to ease. Given the very high output costs of re-anchoring inflation at target once high inflation becomes entrenched in expectations, there was broad agreement that, at this juncture, the central bank should be biased toward a tight monetary stance. Following the mission, the central bank raised its policy rate by 75 basis points, and markets expect additional increases will be forthcoming.

\section{The authorities viewed the introduction of the preannounced schedule for} monetary policy meetings as successful and stressed that the framework would continue to evolve. It was noted that the preannounced policy meetings had enhanced internal procedures and communication, and helped anchor expectations. There was some agreement with staff's suggestion of having more than 6 preannounced meeting per year, particularly when the time comes to ease policy. Smaller, more frequent steps might allow for more caution. Further, the response has been favorable to the authorities' public discussions of their assessment of the interest rate adjustment necessary to return inflation to target. They expect the presentation of this assessment to become more detailed and explicit as their experience increases. The authorities expressed disagreement with the Mishkin and Herbertsson report ${ }^{5}$ recommendation to alter the way house prices enter the inflation target. The authorities argued, and staff concurred, that house price inflation is often a leading indicator of general inflationary pressures and cannot be ignored. Further, the wide use of headline CPI inflation in indexed contracts means that it is the appropriate index to stabilize from a welfare perspective. However, research will proceed, as staff previously advised, to identify less volatile indices that include house prices and are highly correlated in the

\footnotetext{
${ }^{5}$ The report, entitled "Financial Stability in Iceland", was commissioned by the Iceland Chamber of Commerce and published in May 2006.
} 
medium-term with headline CPI. Once headline CPI inflation has been re-anchored at the target rate, it would then be appropriate to consider alternatives.

\section{Competitiveness}

\section{There was agreement that the year-to-date depreciation in the currency was an} appropriate adjustment from an overvalued level. Although the depreciation, reflecting market forces, occurred sooner and faster than expected, the currency is now close to most observers' estimate of equilibrium. Despite the high degree of uncertainty associated with such estimates, particularly in a country undergoing such large structural changes as Iceland (Box 5), there is broad consensus that the equilibrium for the nominal effective exchange rate (ISK) index lies between 125 and 140. Given the magnitude of imbalances in the economy, most observers expect some undershooting of the exchange rate before it stabilizes in the medium term. The export sector, which has become adept at adjusting to currency

\section{Box 5. The Equilibrium Exchange Rate in Iceland}

The recent sharp widening of the current account balance in Iceland has raised concerns about the country's long-term external sustainability. Using the estimated parameters from Chinn and Ito (2005), the current account balance consistent with long-run balances in saving and investment in Iceland lies in the range of $-1 / 2$ to $-1 \frac{1}{2}$ percent of GDP. ${ }^{1}$ A simple regression of the changes in the current account balance and the real exchange rate suggests that the real exchange rate would need to depreciate by roughly 10-15 percent to bring down the deficit to the level implied by the S-I norm. Such adjustment could take the form of lower inflation or depreciation in the nominal exchange rate, but assuming that inflation will decline to target, the implied equilibrium rate for the nominal ISK exchange rate index would need to be in the range of 125-140 (at the end of June the ISK index stood at 130). However, estimating the equilibrium exchange rate entails large uncertainties. This is in part attributed to differences in methodology, the choice of variables used as proxies for the fundamental determinants of the equilibrium rate, and the period studied. Also, the various estimation approaches are particularly difficult to implement in a country like Iceland, where substantial structural change in recent years make underlying economic relationships unstable. Moreover, it is not clear whether such adjustment will stabilize the ratio of net foreign assets to GDP given the growing role played by banks' assets in the Iceland's net IIP position.
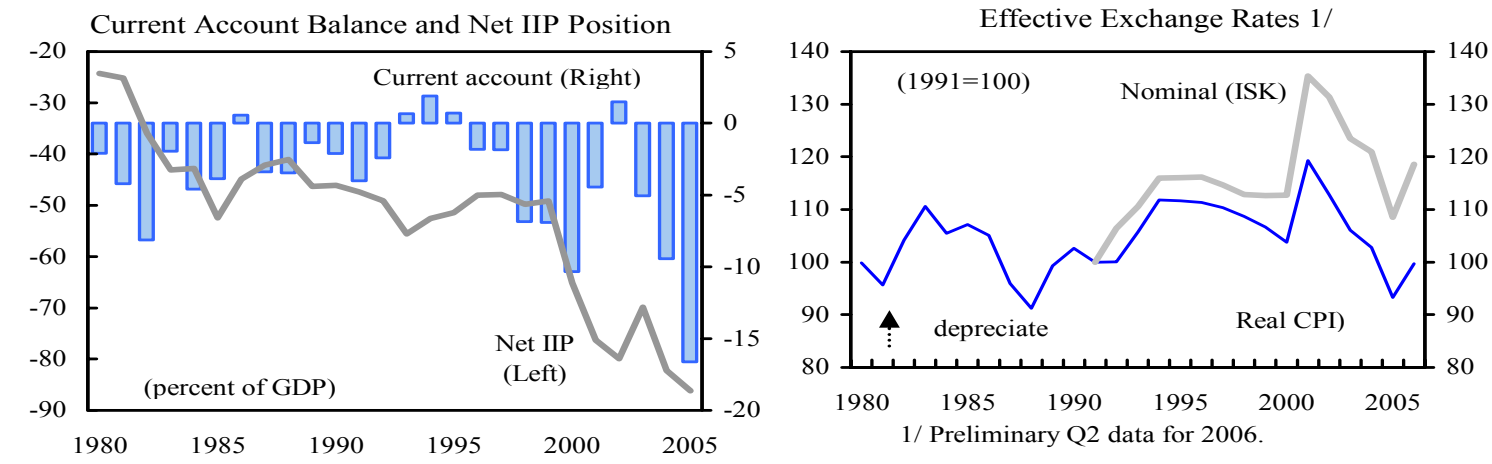

${ }^{1}$ Chinn and Ito (2005), “Current Account Balances, Financial Development and Institutions: Assaying the World Saving Glut”, NBER Working Paper 11761, November 2005. 
fluctuations, will nevertheless receive a needed boost to profitability. In turn this should spur investment, further improving competitiveness.

22. Although there are pockets of support, euro adoption is not broadly viewed to be viable for Iceland. The authorities noted that support for euro adoption only arises during periods of market stress. Even those currently in favor see it as part of a medium-term rather than a near-term strategy. Those opposed argue that the probability is quite low that euro area monetary policy would ever be set appropriately for Iceland's cyclical conditions. For example, it was noted that the current boom could have been much larger if Iceland had enjoyed euro area interest rates.

\section{E. The Financial Sector}

\section{There was consensus that banks' rapid expansion had increased their risk} profile, but measures have and should continue to be taken to make those risks manageable (Box 6). The authorities shared staff's view that the key risks in the banking sector were liquidity, credit, and interconnectedness through crossholdings of equity. The discussions revealed the following:

- banks have taken considerable steps to ensure their liquidity requirements are met (see Box 6 for details);

- $\quad$ credit quality has remained high and appears robust to large movements in exchange and interest rates; and

- crossholdings of equity are being reduced and associated connected lending is monitored closely by supervisors.

Despite the steps banks have taken, there was broad agreement among staff, supervisors, and banks that the process needs to continue. In particular, banks must further diversify their funding, grow their balance sheets cautiously, be increasingly vigilant regarding credit quality, and continue to reduce crossholdings of equity. 


\section{Box 6. Assessment of the Risks in the Icelandic Banking Sector}

The mission assessed the vulnerability of the banking system - of which Kaupthing, Landsbanki and Glitnir represent more than 80 percent - to the main risks: credit, liquidity, and interconnectedness through the crossholdings of equity.

- Liquidity risk: The high rate of asset growth of banks and a low deposit base imply that banks are heavily reliant on wholesale funding, mostly from international investors.
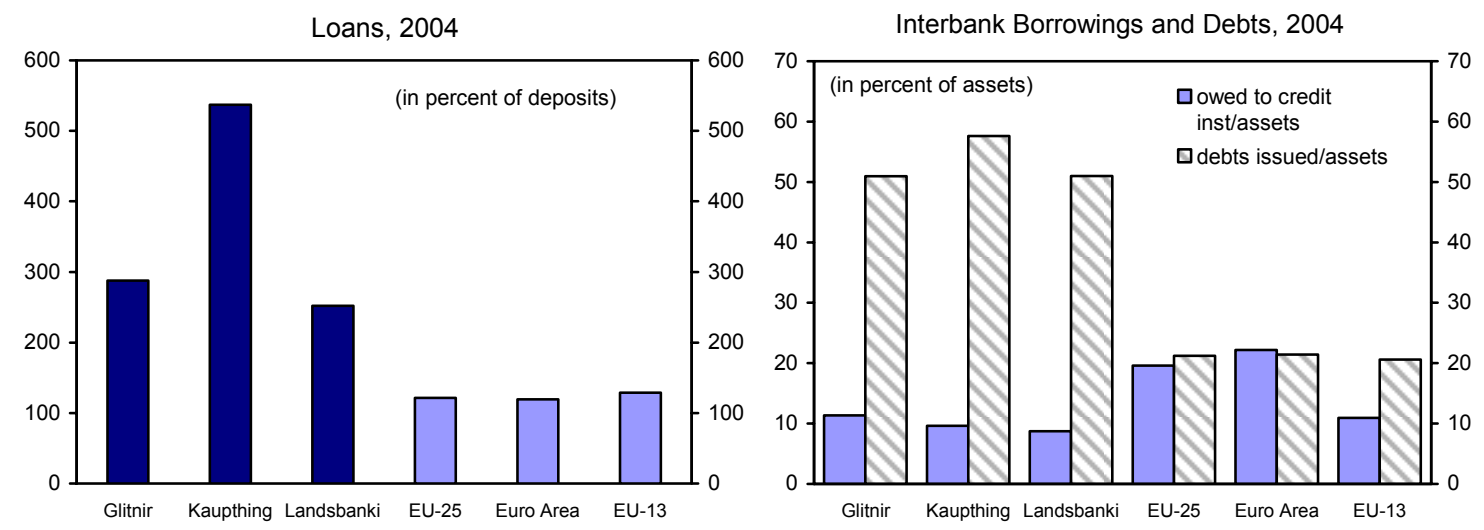

The refusal, early in the year, of US money market funds to rollover the banks' 13-month extendible debts signaled the likelihood of banks facing higher refinancing costs. Bank bond prices have fallen with spreads (above EURIBOR) rising to $100 \mathrm{bp}$ before settling at $60 \mathrm{bp}$ recently. Although all three banks face heavy refinancing needs in 2006-07, discussions with the banks and the FME suggested that there is no immediate threat of a liquidity crunch due to lack of market access. Although foreign liabilities maturing in 3-6months are more than covered by liquid assets (excluding market securities and credit lines), those maturing in 6-12 months are not. However, banks have mostly closed their 2006 funding gap, and have credible plans for closing 2007 needs. In addition, banks have to meet the central bank mandated liquidity ratio of over 1 in the 0 3 month horizon and banks have developed foreign exchange liquidity management policies and contingency plans based on FME guidelines.

The vulnerability to liquidity risks is partly mitigated by:

- committed back-up facilities, mostly from European banks;

- banks' steps to diversify their global investor base and lengthen maturities, which has now increased to average 3-5 years;

- growing deposit bases, especially of subsidiaries; and

- securitization.

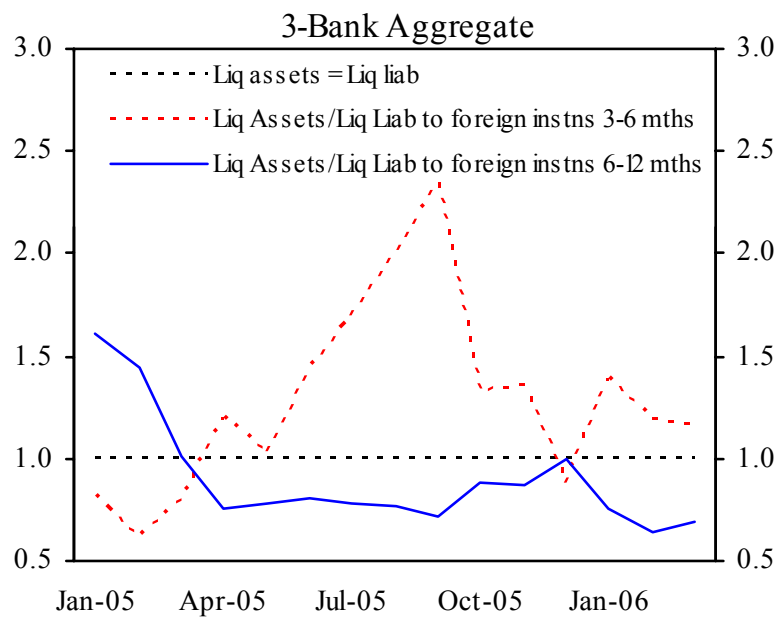




\section{Box 6. Assessment of the Risks in the Icelandic Banking Sector (cont'd)}

If banks used bond issues to close their 6-12 month liquidity gap, the extra refinancing cost is estimated to have a small impact on profitability - less than $1 / 2$ percentage point of aggregate return on assets (ROA) at a spread of $100 \mathrm{bp}$.

- Credit risk: Credit growth averaging 44 percent y-o-y 2003-05, in an already deep financial market has increased the risk that loan quality may have been overestimated. Although default rates and the nonperforming loan (NPL) ratio are low, these are susceptible to rapid increases when the cycle turns.

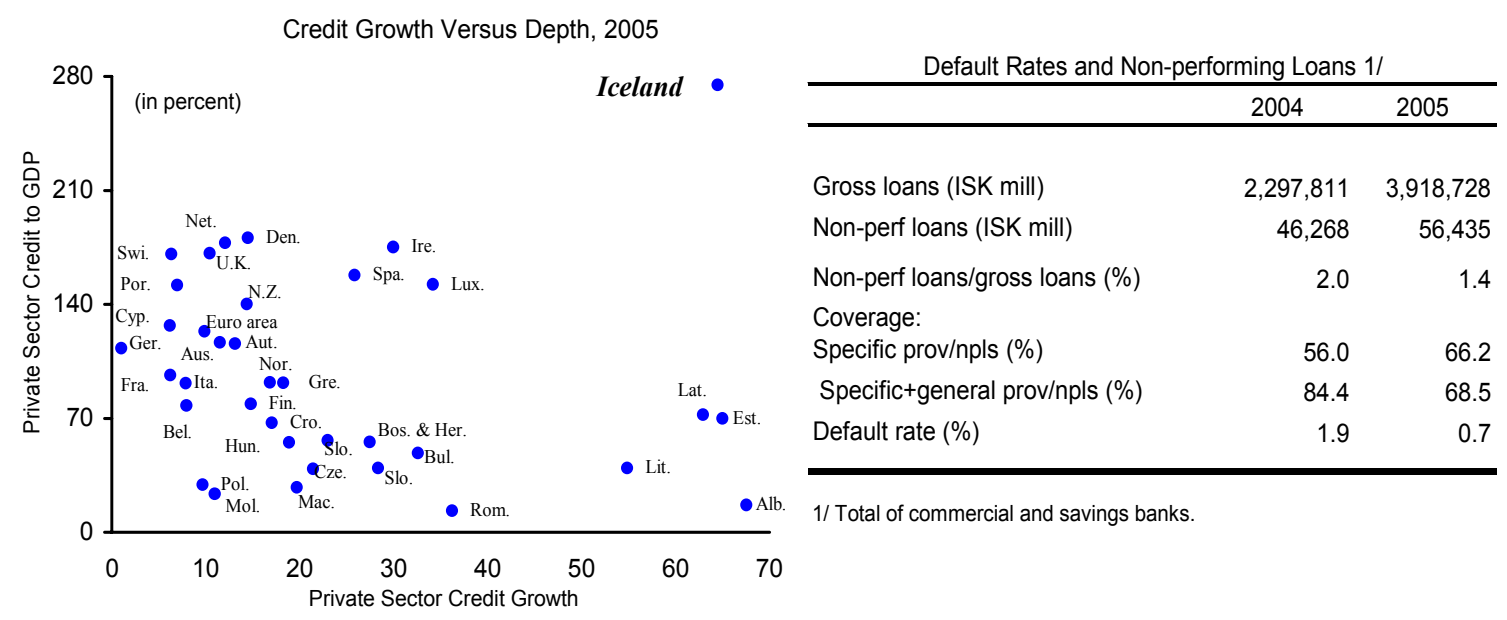

The FME estimates that the nominal value of NPLs rose by 22 percent y-o-y 2004-05. Being a backwardlooking indicator, the NPL ratio can turn with a down-cycle due to highly leveraged counterparties - private sector debt/GDP ratio is nearly 200 percent. But, given that most fx loans are made to hedged customers and most household loan contracts are indexed to inflation, the impact of exchange rate and interest rate changes on loan quality is expected to be small.

Banks' exposure to credit risk could be aggravated by the following vulnerabilities, although accompanying mitigants exist:

- Crossholdings: The complex web of ownership extends to crossholdings by banks of companies they lend to. This reduces transparency while exposing banks to double-sided risks of being hit on the assets by declining equity prices of their crossholdings, and on capitalization from possible deterioration of credit quality of the borrower. However, banks require equity-collateral of 150-200 percent of the loan, with margin calls starting at 140-160 percent (varying by banks). Also, FME deducts equity holdings in financial companies from banks' regulatory capital. All three banks have started reducing crossholdings and this process needs to continue.

- Connected lending: The FME monitors connected lending through its guidelines and reporting requirements to ensure loans to connected parties are made on an arm's length basis. However, the FME does not have a mandate to set up limits on such loans, to deduct their amounts from capital, or to require banks to collateralize them. 


\section{Traditional indicators of financial sector health suggest the banks remain sound.}

Stress tests performed by the FME and central bank indicate that bank capital appears adequate to withstand large shocks (Box 7). Profitability, although having recently been driven to record highs by gains from equity trading and exchange rate movements, should remain strong in the absence of these factors. Core profitability has been increasing, in part reflecting the impact of banks' foreign expansion.

\section{Box 7. Stress Tests on Solvency of the Banking System}

Overall, the banking sector achieved record ROA in 2006Q1, but vulnerabilities have slightly increased. FME stress tests done quarterly show that the system is resilient to the simultaneous occurrence of large shocks - increase in write-off of non-performing loans/impaired loans by 20 percent, write-offs of non-mortgage and mortgage loans increasing to their historical highs (1.8 and 0.2 percent respectively), price declines of 35 percent in domestic equities and 25 percent in foreign equities, fall in marketable bond portfolio by 7 percent, and depreciation of the ISK index by 25 percent. Applying the tests on 2005Q4 and 2006Q1 results shows that the post-shock capital adequacy ratio (CAR) is marginally closer to the 8 percent minimum in 2006Q1 than in 2005Q4. Each of the bars in the figure show the post-shock effect of each of the tests and all tests together on the CAR.

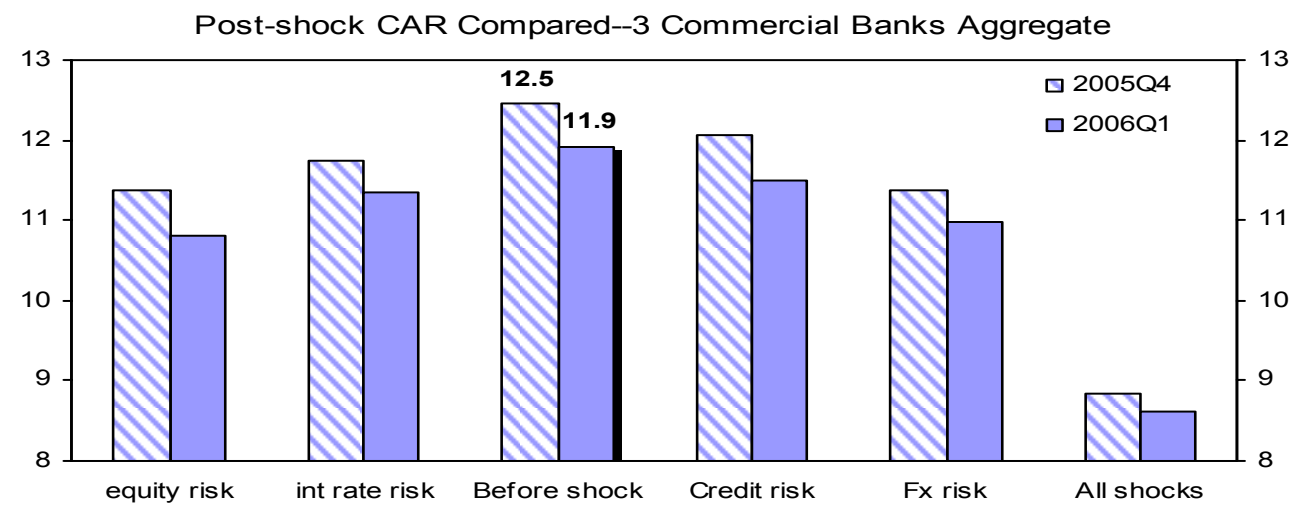

The design and magnitudes of the shocks, except the interest rate shock, provide an adequate stress test of the banking system. The CAR is sensitive to the design of the interest rate shock - duration and magnitude - on the trading bond portfolio. It would be preferable if the test was based on the likely change in interest rates along the yield curve as domestic and global monetary policy conditions tighten, rather than by value of portfolio. To enhance transparency, the assumptions underlying the stress tests (especially "credit risk 1") could be discussed more on the website and with the banks. Encouragingly, the FME has decided not to reduce the stringency of the test following the large adjustments in markets that have occurred year-to-date.

\section{The supervisory and financial stability frameworks continue to be strengthened.}

The FME has now implemented most of the FSAP recommendations including issuing guidelines on connected lending and monitoring of country risk. Consistent with previous Article IV recommendations, capital-adequacy stress tests have been broadened and made more stringent. The central bank and the FME have strengthened their cooperation and 
recently undertook a joint contingency exercise simulating various stress scenarios. Early in the year, a Memorandum of Understanding was signed by the relevant ministries, the central bank, and the FME on consultation concerning financial stability and contingency plans in the event of severe stress.

\section{STAFf Appraisal}

26. Although current imbalances need to be addressed resolutely, the medium-term outlook for the Icelandic economy remains highly favorable. At the current juncture, mounting imbalances in the current account, excess demand, and inflation, plus the associated threats to stability are concerns that policymakers must address promptly. However, the structural fundamentals are sound. Institutions and policy frameworks are strong. Markets are open and flexible, and the skillful management of the country's natural endowments has diversified the economy and helped to ensure sustainability. Further, these factors are combined with a culture of entrepreneurial dynamism that has led to economic outcomes that belie the country's small size.

\section{Although public debt is low and declining, an adjustment to the current fiscal} plan is required to reduce imbalances and avert related risks. Macroeconomic imbalances that are wider than expected at the time of the 2006 budget have increased the risk that the economy could experience an abrupt and disruptive contraction. The downturn could be exacerbated if international financial market conditions become less favorable for Iceland. On current plans, the fiscal surplus will decline in 2006 relative to what was achieved in 2005. The high growth budgeted for nominal public consumption should be reduced and more public investment should be delayed to maintain fiscal restraint in 2006 at the same level as in 2005. The government ought to announce that additional fiscal restraint will be introduced in the budget for 2007 if domestic demand pressures do not abate as required. Areas for potential adjustment include planned tax cuts, public investment, and public consumption.

\section{The fiscal framework should continue to be strengthened to help reduce the} volatility in the Icelandic economy in the future. The introduction of multi-year budgeting was the first step along the path to a rules-based framework. The next step is to add more structure to the budgeting and implementation processes to ensure that fiscal policy provides consistent and substantial offsets to the fluctuations in private demand that have generated large swings in economic activity in Iceland. Such a systematic approach to fiscal policy would consistently reinforce monetary policy and increase economic stability.

\section{Further increases in the policy rate, sufficient to increase real interest rates, will} be required to anchor expectations, and return inflation to target. Although house prices, which have driven inflation well above target in the recent past, are starting to show some signs of moderation, rising prices of imported and domestic goods and services are forecast to keep inflation persistently high for an extended period. 
30. Given the high output cost of returning inflation to target should expectations of high inflation become entrenched, the central bank should be biased toward a tight monetary stance. There are comforting signs that monetary policy is starting to have more of an impact on the credit conditions faced by households and firms, and these developments will need to be monitored carefully to gauge the appropriate degree of monetary restraint. Moreover, inflation expectations should now be better anchored with the introduction of the preannounced schedule of monetary policy meetings and the central bank's open discussion of the interest rate path required to return inflation to target.

31. The flexible exchange rate regime, introduced in 2001, has worked well. Although high domestic interest rates attracted carry trade investors, contributing to exchange rate variability, domestic agents did not taken significant currency exposure. Consequently, the depreciation in the exchange rate early in the year, which has moved the currency close to its equilibrium value, has not adversely affected domestic balance sheets.

\section{The financial system appears sound, but actions should continue to be taken to} reduce vulnerabilities. The balance sheets of Icelandic banks have been growing at a remarkable pace. International markets are concerned that this pace of growth has exposed the Icelandic financial system to vulnerabilities that could undermine its health as the economy adjusts to restore balance. Potential vulnerabilities include considerable near-term refinancing needs, credit quality, the long-term sustainability of the banks' presence in the domestic mortgage market, and the crossholdings of equity. Banks are taking significant steps to meet their funding needs over the near term. Should systemic issues arise, the authorities have put in place a consultation process and contingency plans to support financial stability. In addition, the banks have begun reducing crossholdings of equity, thereby making ownership structures more transparent. At this point in the economic cycle, it will also be important for banks to be increasingly vigilant regarding credit quality. Given global credit conditions, banks need to expand their balance sheets more cautiously than in the recent past and diversify their funding. Stress tests performed by the central bank and the FME suggest that banks' capitalization can withstand very large shocks. Should there be a sharp downturn in the economy, the impact would likely show up in reduced profitability through a reversal of trading gains, higher financing costs, and increases in non-performing loans.

\section{The continued strengthening of the supervisory framework is welcome. For} example, the broadening and increased stringency in the stress tests should provide positive assurance for international markets, as should the banks' willingness to make the bank-bybank results of these tests public. To further improve the stress tests, the FME should make the interest rate component more closely match how interest rates along the yield curve adjust as monetary policy tightens.

34. The HFF needs immediate reform. The competition between the banks and the state-subsidized HFF has undermined the effectiveness of monetary policy, unnecessarily 
exacerbated macroeconomic imbalances, and threatened financial stability. The initial reform proposal, with continued public ownership, falls short of what is required. Instead, winding down the existing HFF and creating a new privately-held wholesale funding institution would retain important economies of scale in mortgage funding and allow for healthy competition among the banks in the mortgage market. As international experience proves, the social objective of adequate access to mortgage financing can be achieved with more efficient and targeted public programs.

35. It is recommended that the next Article IV consultation occur on the 12-month cycle. 
Table 1. Iceland: Selected Economic Indicators, 2000-07

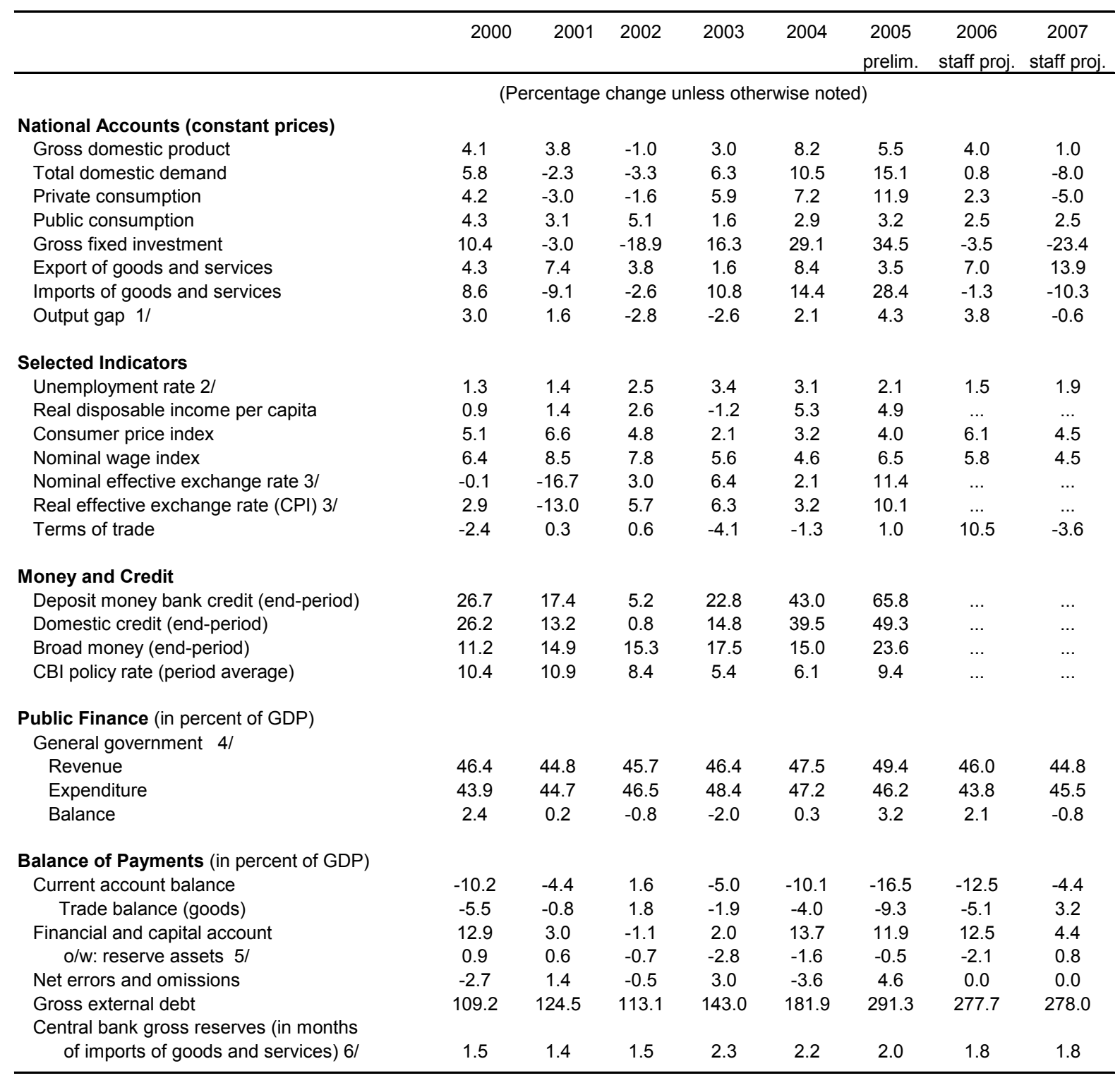

Sources: Statistics Iceland; Central Bank of Iceland; Ministry of Finance; and staff estimates.

1/ Staff estimates. Actual minus potential output, in percent of potential output.

2/ In percent of labor force.

3/ A positive (negative) sign indicates an appreciation (depreciation).

4/ National accounts basis.

5/ A positive (negative) sign indicates a decrease (increase) in gross official foreign reserves.

6/ Excluding imports from the construction of hydropower facility and smelters in 2003-04. 
Table 2. Iceland: Balance of Payments, 2000-05

\begin{tabular}{|c|c|c|c|c|c|c|}
\hline & 2000 & 2001 & 2002 & 2003 & 2004 & 2005 \\
\hline & \multicolumn{6}{|c|}{ (millions of krónur) } \\
\hline Current Account & $-69,439$ & $-33,365$ & 12,627 & $-41,039$ & $-92,195$ & $-164,458$ \\
\hline Balance on Goods & $-37,480$ & $-5,936$ & 14,082 & $-15,900$ & $-36,547$ & $-93,100$ \\
\hline Merchandise exports f.o.b. & 149,272 & 196,582 & 204,303 & 182,580 & 202,373 & 194,934 \\
\hline Merchandise imports f.o.b. & $-186,752$ & $-202,518$ & $-190,221$ & $-198,480$ & $-238,920$ & $-288,034$ \\
\hline Balance on Services & $-11,637$ & $-1,549$ & -718 & $-9,150$ & $-14,427$ & $-34,298$ \\
\hline Exports of services, total & 80,248 & 102,830 & 101,171 & 105,647 & 113,918 & 125,656 \\
\hline Imports of services, total & $-91,885$ & $-104,379$ & $-101,889$ & $-114,797$ & $-128,345$ & $-159,954$ \\
\hline Balance on Income & $-19,560$ & $-24,921$ & $-1,907$ & $-14,823$ & $-40,041$ & $-35,346$ \\
\hline Receipts & 11,414 & 16,634 & 27,158 & 28,548 & 32,640 & 94,070 \\
\hline Expenditures & $-30,974$ & $-41,555$ & $-29,065$ & $-43,371$ & $-72,681$ & $-129,416$ \\
\hline Current transfer, net & -762 & -959 & 1,170 & $-1,166$ & $-1,180$ & $-1,714$ \\
\hline Capital and Financial Account & 87,471 & 22,845 & $-8,396$ & 16,309 & 125,588 & 118,208 \\
\hline Capital transfer, net & -222 & 362 & -122 & -402 & -234 & $-1,697$ \\
\hline Financial Account & 87,693 & 22,483 & $-8,274$ & 16,711 & 125,822 & 119,905 \\
\hline Direct investment, net & $-17,510$ & $-16,801$ & $-21,306$ & $-4,087$ & $-128,107$ & $-285,843$ \\
\hline Abroad & $-30,969$ & $-33,734$ & $-29,646$ & $-28,518$ & $-179,754$ & $-439,165$ \\
\hline In Iceland & 13,459 & 16,933 & 8,340 & 24,431 & 51,647 & 153,322 \\
\hline Portfolio investment, net & 54,928 & 65,413 & 13,650 & 227,969 & 474,546 & 780,113 \\
\hline Assets & $-38,593$ & $-1,752$ & $-28,838$ & $-45,351$ & $-107,299$ & $-283,889$ \\
\hline Liabilities & 93,521 & 67,165 & 42,488 & 273,320 & 581,845 & $1,064,002$ \\
\hline Other investment, net & 44,574 & $-30,948$ & 5,046 & $-183,770$ & $-206,387$ & $-369,645$ \\
\hline Assets & $-7,112$ & $-47,101$ & $-30,426$ & $-156,116$ & $-237,570$ & $-687,549$ \\
\hline Liabilities & 51,686 & 16,153 & 35,472 & $-27,654$ & 31,183 & 317,904 \\
\hline Reserve assets & 5,794 & 4,819 & $-5,664$ & $-23,401$ & $-14,230$ & $-4,720$ \\
\hline \multirow[t]{2}{*}{ Net errors and omissions } & $-18,032$ & 10,520 & $-4,231$ & 24,730 & $-33,393$ & 46,250 \\
\hline & \multicolumn{6}{|c|}{ (in percent of GDP) } \\
\hline Current Account & -10.2 & -4.4 & 1.6 & -5.0 & -10.1 & -16.5 \\
\hline Balance on Goods & -5.5 & -0.8 & 1.8 & -1.9 & -4.0 & -9.3 \\
\hline Merchandise exports f.o.b. & 22.0 & 25.7 & 25.6 & 22.1 & 22.1 & 19.6 \\
\hline Merchandise imports f.o.b. & -27.5 & -26.5 & -23.8 & -24.0 & -26.1 & -28.9 \\
\hline Balance on Services & -1.7 & -0.2 & -0.1 & -1.1 & -1.6 & -3.4 \\
\hline Exports of services, total & 11.8 & 13.4 & 12.7 & 12.8 & 12.4 & 12.6 \\
\hline Imports of services, total & -13.5 & -13.6 & -12.7 & -13.9 & -14.0 & -16.1 \\
\hline Balance on Income & -2.9 & -3.3 & -0.2 & -1.8 & -4.4 & -3.5 \\
\hline Receipts & 1.7 & 2.2 & 3.4 & 3.4 & 3.6 & 9.4 \\
\hline Expenditures & -4.6 & -5.4 & -3.6 & -5.2 & -7.9 & -13.0 \\
\hline Current transfer, net & -0.1 & -0.1 & 0.1 & -0.1 & -0.1 & -0.2 \\
\hline Capital and Financial Account & 12.9 & 3.0 & -1.1 & 2.0 & 13.7 & 11.9 \\
\hline Capital transfer, net & 0.0 & 0.0 & 0.0 & 0.0 & 0.0 & -0.2 \\
\hline Financial Account & 12.9 & 2.9 & -1.0 & 2.0 & 13.7 & 12.0 \\
\hline Direct investment, net & -2.6 & -2.2 & -2.7 & -0.5 & -14.0 & -28.7 \\
\hline Abroad & -4.6 & -4.4 & -3.7 & -3.4 & -19.6 & -44.1 \\
\hline In Iceland & 2.0 & 2.2 & 1.0 & 3.0 & 5.6 & 15.4 \\
\hline Portfolio investment, net & 8.1 & 8.6 & 1.7 & 27.5 & 51.8 & 78.3 \\
\hline Assets & -5.7 & -0.2 & -3.6 & -5.5 & -11.7 & -28.5 \\
\hline Liabilities & 13.8 & 8.8 & 5.3 & 33.0 & 63.5 & 106.8 \\
\hline Other investment, net & 6.6 & -4.0 & 0.6 & -22.2 & -22.5 & -37.1 \\
\hline Assets & -1.0 & -6.2 & -3.8 & -18.9 & -25.9 & -69.0 \\
\hline Liabilities & 7.6 & 2.1 & 4.4 & -3.3 & 3.4 & 31.9 \\
\hline Reserve assets & 0.9 & 0.6 & -0.7 & -2.8 & -1.6 & -0.5 \\
\hline Net errors and omissions & -2.7 & 1.4 & -0.5 & 3.0 & -3.6 & 4.6 \\
\hline
\end{tabular}

Source: Central Bank of Iceland. 
Table 3. Iceland: Financial Soundness Indicators, 1998-2005

\begin{tabular}{|c|c|c|c|c|c|c|c|c|c|}
\hline & 1998 & 1999 & 2000 & 2001 & 2002 & 2003 & 2004 & 2005 & as of \\
\hline Capital adequacy & 10.4 & 10.4 & 9.8 & 11.4 & 12.2 & 12.3 & 12.8 & 12.8 & \\
\hline Risk-based capital adequacy ratio (CAR) 1/3/ & 8.7 & 8.0 & 6.6 & 8.1 & 9.1 & 9.2 & 9.5 & 7.6 & year-end \\
\hline CAR excluding subordinated loans & 9.9 & 9.3 & 8.1 & 9.1 & 9.7 & 9.7 & 10.4 & 10.2 & year-end \\
\hline Tier 1 capital ratio & 86.7 & 82.9 & 79.7 & 66.7 & 71.9 & $\cdots$ & & & year-end \\
\hline \multicolumn{10}{|l|}{ Asset quality } \\
\hline Credit institutions & 385.7 & 475.8 & 601.5 & 704.3 & 740.2 & 918.6 & $1,314.0$ & $2,203.0$ & \\
\hline $\begin{array}{l}\text { Total lending (in ISK billion) } \\
\text { thereof foreign currency loans (in percent) }\end{array}$ & 34.4 & 36.5 & 41.6 & 44.3 & 39.6 & 49.0 & 51.3 & 51.9 & $\begin{array}{l}\text { year-end } \\
\text { year-end }\end{array}$ \\
\hline Sectoral credit concentration & 6.3 & 6.8 & 6.6 & 5.8 & 5.3 & $\ldots$ & $\ldots$ & $\ldots$ & \\
\hline Real estate loans (as percent of total loans) & 27.7 & 24.8 & 22.9 & 21.2 & 17.1 & 13.4 & 10.9 & 10.9 & \\
\hline Loans to fisheries (as percent of total loans) & 83.3 & 83.9 & 86.5 & 86.8 & 87.0 & 90.1 & 90.3 & 84.0 & year-end \\
\hline thereof foreign currency loans (in percent) & 27.9 & 27.3 & 27.5 & 25.5 & 26.3 & 20.1 & 23.5 & 24.6 & year-end \\
\hline Loans to households (as percent of total loans) 2/ & 1.8 & 4.8 & 8.1 & 10.4 & 8.6 & 4.1 & 7.0 & 5.2 & year-end \\
\hline thereof foreign currency loans (in percent) & 64.8 & 65.7 & 65.2 & 64.2 & 62.6 & 61.9 & 59.1 & 50.5 & year-end \\
\hline Loans to businesses (as percent of total loans) & 49.8 & 50.6 & 55.6 & 54.7 & 49.4 & 56.9 & 57.1 & 54.1 & year-end \\
\hline thereof foreign currency loans (in percent) & 24.8 & 28.6 & 29.4 & 30.0 & 32.7 & 35.5 & 37.7 & 33.4 & year-end \\
\hline Loans to retail and services (as percent of total loans) & 19.5 & 29.5 & 37.0 & 36.1 & 33.7 & 49.9 & 51.6 & 50.0 & year-end \\
\hline thereof foreign currency loans (in percent) & 12.3 & 12.2 & 12.9 & 13.0 & 12.7 & 12.3 & 10.0 & 7.1 & year-end \\
\hline Loans to manufacturing et. al. (as percent of total loans) & 35.5 & 32.4 & 43.0 & 45.3 & 39.2 & 42.1 & 43.4 & 42.4 & year-end \\
\hline thereof foreign currency loans (in percent) & $\ldots$ & $\ldots$ & $\ldots$ & 3.6 & 6.2 & 12.3 & 14.6 & 22.8 & year-end \\
\hline Foreign sector (as percent of total loans) & & $\ldots$ & $\ldots$ & 99.4 & 78.6 & 91.2 & 96.1 & 96.6 & year-end \\
\hline thereof foreign currency loans (in percent) & 1.4 & 1.6 & 1.5 & 2.0 & 2.6 & 2.1 & 0.9 & $\ldots$ & year-end \\
\hline Non-performing loans (NPL) as percent of total loans $1 / 4$ / & 1.0 & 0.9 & 0.8 & 1.2 & 1.2 & 1.4 & 0.8 & 0.3 & year-end \\
\hline $\begin{array}{l}\text { Total provisions as percent of average loans } 1 / \\
\text { Leverage ratio (equity as percent of total assets) } 1 /\end{array}$ & n.a. & n.a. & n.a. & n.a. & n.a. & $\ldots$ & & & $\begin{array}{l}\text { year-end } \\
\text { year-end }\end{array}$ \\
\hline \multicolumn{10}{|l|}{ Borrowing entities } \\
\hline Debt-equity ratios & 1.9 & 2.1 & 2.3 & 2.3 & 1.7 & 1.8 & 2.1 & 1.9 & \\
\hline All listed companies (except financial companies) & 1.8 & 1.9 & 2.6 & 2.6 & 2.0 & 2.0 & 1.8 & 2.4 & year-end \\
\hline Fisheries companies & 1.7 & 1.3 & 1.5 & 1.4 & 1.4 & 1.6 & 1.5 & 2.2 & year-end \\
\hline Manufacturing companies & 2.9 & 2.3 & 1.8 & 1.4 & 1.1 & 1.0 & 1.9 & 2.0 & year-end \\
\hline IT companies & 2.3 & 2.8 & 1.9 & 2.0 & 1.5 & 1.4 & 3.2 & 1.6 & year-end \\
\hline Retail, services, and construction companies & & & & & & & & & year-end \\
\hline Corporate profitability (EBITDA/turnover) & 8.2 & 7.3 & 7.8 & 10.2 & 11.9 & 11.1 & 11.2 & 10.1 & \\
\hline All listed companies (except financial companies) & 17.8 & 14.7 & 17.4 & 27.1 & 24.0 & 21.3 & 17.5 & 18.7 & year-end \\
\hline Fisheries companies & 9.3 & 7.5 & 12.5 & 13.4 & 12.9 & 11.0 & 19.0 & 15.9 & year-end \\
\hline Manufacturing companies & 6.1 & 8.7 & 9.0 & 10.2 & 27.2 & 23.4 & 13.9 & 9.3 & year-end \\
\hline IT companies & 4.7 & 5.6 & 7.9 & 5.6 & 7.5 & 10.5 & 12.1 & 12.1 & year-end \\
\hline Retail, services, and construction companies & 146.1 & 160.9 & 165.4 & 176.9 & 182.4 & 172.0 & 183.5 & 214.7 & year-end \\
\hline Household indebtedness (debt/disposable income) 5/ & & & & & & & & & year-end \\
\hline \multicolumn{10}{|l|}{ Management soundness $1 /$} \\
\hline Expense ratios & 67.9 & 61.8 & 65.7 & 66.7 & 59.4 & 55.0 & 45.1 & 35.8 & \\
\hline $\begin{array}{l}\text { Operating expenses as percent of net operational revenue } \\
\text { Staff costs as percent of net operational revenue }\end{array}$ & 35.6 & 31.9 & 32.9 & 33.8 & 30.9 & 29.4 & 23.9 & $\ldots$ & $\begin{array}{l}\text { year-end } \\
\text { year-end }\end{array}$ \\
\hline Earnings and profitability $1 / 3 /$ & 0.9 & 1.2 & 0.7 & 0.8 & 1.1 & 1.3 & 1.8 & 2.3 & \\
\hline Return on assets & 13.8 & 18.6 & 10.7 & 13.5 & 18.1 & 22.1 & 30.9 & 41.7 & year-end \\
\hline Return on equity & 56.3 & 53.1 & 54.5 & 63.8 & 51.4 & 44.2 & 40.7 & 39.7 & year-end \\
\hline Interest margin (as percent of total revenue) & 23.5 & 23.7 & 31.0 & 32.6 & 26.2 & 25.0 & 21.3 & 24.1 & year-end \\
\hline Fees and commissions (as percent total revenue) & 14.7 & 12.4 & $(1.2)$ & $(5.8)$ & 12.1 & 22.7 & 24.7 & 26.5 & year-end \\
\hline Value adjustments of other financial operations & & & & & & & & & year-end \\
\hline (as percent of total revenue) & 3.6 & 7.9 & 5.9 & 4.0 & 2.7 & 3.2 & 3.9 & 3.0 & \\
\hline Dividends from shares and other holdings & 1.9 & 2.9 & 9.8 & 5.3 & 7.6 & 4.9 & 9.3 & 6.7 & year-end \\
\hline Other income (as percent of total revenue) & & & & & & & & & year-end \\
\hline
\end{tabular}


Table 3. Iceland: Financial Soundness Indicators (concluded)

\begin{tabular}{|c|c|c|c|c|c|c|c|c|c|c|c|}
\hline & & 1998 & & 1999 & 2000 & 2001 & 2002 & 2003 & 2004 & 2005 & as of \\
\hline \multicolumn{12}{|l|}{ Liquidity } \\
\hline Central bank credit to banks (end of period, in ISK billion) & & 22.8 & & 36.0 & 46.9 & 68.7 & 73.7 & 25.0 & 37.5 & 87.7 & year-end \\
\hline Deposits to $\mathrm{M} 3$ ratio & & 1.0 & & 1.0 & 1.0 & 1.0 & 1.0 & 1.0 & 1.0 & 1.1 & year-end \\
\hline Loans-to-deposits ratio & & 1.5 & & 1.5 & 2.1 & 2.1 & 1.9 & 1.9 & 2.4 & 3.2 & year-end \\
\hline \multicolumn{12}{|l|}{ Liquidity ratio (cash and short-term assets/ } \\
\hline \multicolumn{12}{|l|}{ Measures of secondary market liquidity: } \\
\hline Interbank FX market turnover (Kr. Billions) & & 401.8 & & 468.0 & 768.0 & $1,218.0$ & 834.4 & $1,185.6$ & 949.9 & $2,077.5$ & year-end \\
\hline Interbank domestic market turnover (Kr. Billions) & & 447.7 & & 502.9 & 524.3 & 426.1 & 420.8 & 578.9 & $1,073.3$ & $1,579.1$ & year-end \\
\hline \multicolumn{12}{|l|}{ Market-based indicators: } \\
\hline Stock market index (ICEX-15; y-o-y change) & & 9.8 & & 47.4 & -19.3 & -11.2 & 16.7 & 56.4 & 58.9 & 64.7 & year-end \\
\hline Residential housing prices (y-o-y increase) & & 7.8 & & 22.2 & 13.3 & 3.1 & 7.5 & 9.1 & 23.3 & 31.0 & year-end \\
\hline Commercial property prices (y-o-y increase) (between yearly averages) & & 15.8 & & 24.9 & 16.3 & -2.8 & -12.6 & 11.6 & 6.9 & 12.6 & year-end \\
\hline Market capitalization at year-end/GDP & & 39.9 & & 57.6 & 59.5 & 57.0 & 68.2 & 81.3 & 126.2 & 1.8 & year-end \\
\hline Turnover rate (trading/market capitalization) (12 month trading) & & 17.3 & & 32.4 & 50.0 & 32.4 & 60.8 & 84.0 & 0.7 & 0.7 & year-end \\
\hline \multicolumn{12}{|l|}{ Credit ratings } \\
\hline Moody's short-term & $\mathrm{P} 2$ & & P2 & & $\mathrm{P} 1-\mathrm{P} 2$ & P1-P2 & $\mathrm{P} 1-\mathrm{P} 2$ & $\mathrm{P} 1$ & $\mathrm{P} 1$ & $\mathrm{P} 1$ & year-end \\
\hline Moody's long-term & A3 & & A3 & & $\mathrm{A} 2-\mathrm{A} 3$ & $\mathrm{~A} 2-\mathrm{A} 3$ & $\mathrm{~A} 2-\mathrm{A} 3$ & $\mathrm{~A} 1-\mathrm{A} 3$ & $\mathrm{~A} 1-\mathrm{A} 3$ & $\mathrm{~A} 1-\mathrm{A} 2$ & year-end \\
\hline Fitch short-term & $\ldots$ & & $\ldots$ & & $\ldots$ & F1 & F1 & F1 & F1 & F1 & year-end \\
\hline Fitch long-term & $\ldots$ & & $\ldots$ & & $\ldots$ & $A$ & $A$ & $A$ & $A$ & $A$ & year-end \\
\hline $\begin{array}{l}\text { Sovereign yield spreads (spread between yields on } \\
\text { Icelandic and foreign trade-weighted 3-month T-bills) }\end{array}$ & & 3.4 & & 5.7 & 6.3 & 7.9 & 3.1 & 2.8 & 5.3 & 6.2 & year-end \\
\hline
\end{tabular}

Sources: Financial Supervisory Authority and Central Bank of Iceland.

1/ Commercial banks and six largest savings banks. Fisheries Investment Fund and Industrial Loan Fund included 1996-1997. FBA include 1998-1999. Kauphting Inc. included from year 1996. Figures for Islandsbanki include both the banking and insurance part of the corporation. 2/ Deposit money banks, adjusted for FBA and Commercial Loan Fund. Kaupthing bank Inc. included from year 2002 and Glitnir included from May 2003. Figures from year 2003 onwards for sectoral breakdown of lendings is not comparable with the past because of new loan classification. 3/ Item "miscellaneous" also includes individuals' private business operations. Changed with new loan classification in year 2003. See note above. 4/ Loans for which special provisions have been posted less specific provisions, and other loans which have been interest frozen. Appropriated assets not included. 2003 
Table 4. Iceland: Summary Operations of the General Government, 2002-07 1/ (in percent of GDP)

\begin{tabular}{|c|c|c|c|c|c|c|c|c|}
\hline & \multirow{3}{*}{2002} & \multirow{3}{*}{2003} & \multirow{3}{*}{2004} & \multirow{3}{*}{$\begin{array}{l}\text { Prel. } \\
2005\end{array}$} & \multicolumn{4}{|c|}{ Proj. } \\
\hline & & & & & \multicolumn{2}{|c|}{2006} & \multicolumn{2}{|c|}{2007} \\
\hline & & & & & MoF & IMF & MoF & IMF \\
\hline Total revenue & 45.7 & 46.4 & 47.5 & 49.4 & 46.4 & 46.0 & 44.6 & 44.8 \\
\hline $\begin{array}{l}\text { Current revenue } \\
\text { of which: }\end{array}$ & 43.8 & 44.5 & 45.6 & 47.6 & 44.6 & 44.2 & 42.7 & 43.0 \\
\hline Direct taxes & 19.7 & 20.4 & 20.6 & 21.8 & 20.3 & 20.2 & 18.6 & 19.2 \\
\hline Indirect taxes & 16.7 & 17.4 & 18.2 & 19.5 & 18.1 & 17.8 & 17.8 & 17.5 \\
\hline Interest income & 2.4 & 1.6 & 1.5 & 1.4 & 1.6 & 1.6 & 1.6 & 1.6 \\
\hline Other current income & 5.1 & 5.0 & 5.3 & 4.9 & 4.6 & 4.6 & 4.7 & 4.7 \\
\hline Capital revenue & 1.9 & 1.9 & 1.9 & 1.9 & 1.8 & 1.8 & 1.8 & 1.8 \\
\hline Total expenditure & 46.5 & 48.4 & 47.2 & 46.2 & 44.6 & 43.8 & 46.0 & 45.5 \\
\hline $\begin{array}{l}\text { Current expenditure } \\
\text { of which: }\end{array}$ & 41.9 & 44.0 & 42.1 & 41.8 & 41.0 & 40.3 & 41.7 & 41.3 \\
\hline Interest expenditure & 2.9 & 2.9 & 2.6 & 2.5 & 2.3 & 2.3 & 2.1 & 2.1 \\
\hline Capital expenditure & 4.6 & 4.4 & 5.1 & 4.4 & 3.6 & 3.5 & 4.3 & 4.2 \\
\hline Primary balance & 2.2 & 0.9 & 2.9 & 5.7 & 4.1 & 4.4 & 0.7 & 1.3 \\
\hline Overall balance & -0.8 & -2.0 & 0.3 & 3.2 & 1.8 & 2.1 & -1.5 & -0.8 \\
\hline \multicolumn{9}{|l|}{ Debt position } \\
\hline General government gross debt & 42.6 & 40.6 & 35.0 & 27.0 & 24.1 & 23.3 & $\ldots$ & 23.1 \\
\hline General government net debt & 22.8 & 23.7 & 21.8 & 12.2 & 10.0 & 9.5 & $\ldots$ & 9.3 \\
\hline \multicolumn{9}{|l|}{ Cyclically adjusted $2 /$} \\
\hline Primary revenue & 43.3 & 44.8 & 45.8 & 47.9 & $\ldots$ & 44.2 & $\ldots$ & 43.1 \\
\hline Primary expenditure & 42.4 & 44.4 & 45.6 & 45.6 & $\ldots$ & 43.2 & $\ldots$ & 43.2 \\
\hline Primary balance & 1.0 & 0.4 & 0.3 & 2.2 & $\ldots$ & 1.0 & $\ldots$ & -0.1 \\
\hline Total revenue & 45.7 & 46.4 & 47.4 & 49.3 & $\ldots$ & 45.8 & $\ldots$ & 44.8 \\
\hline Total expenditure & 45.2 & 47.2 & 48.2 & 48.2 & $\ldots$ & 45.5 & $\ldots$ & 45.3 \\
\hline Overall balance & 0.5 & -0.7 & -0.8 & 1.1 & $\ldots$ & 0.3 & $\ldots$ & -0.5 \\
\hline \multicolumn{9}{|l|}{ Memorandum items: } \\
\hline Real public consumption growth 3 / & 8.2 & 3.5 & 3.6 & 3.7 & 3.4 & 3.9 & 3.3 & 2.8 \\
\hline Output gap 4/ & -2.8 & -2.6 & 2.1 & 4.3 & $\ldots$ & 3.8 & $\ldots$ & -0.6 \\
\hline
\end{tabular}

Sources: Ministry of Finance; and Fund staff estimates and calculations.

1/ Official forecast of the Ministry of Finance as of April 2006.

2/ In percent of potential GDP.

3/ Change in percent, deflated by CPI inflation.

4/ Actual output less potential in percent of potential. 
Table 5. Iceland. Medium-term Scenario, 2003-11

(Percentage change, unless otherwise indicated)

\begin{tabular}{|c|c|c|c|c|c|c|c|c|c|}
\hline & 2003 & 2004 & 2005 & 2006 & 2007 & 2008 & 2009 & 2010 & 2011 \\
\hline Real GDP & 3.0 & 8.2 & 5.5 & 4.0 & 1.0 & 2.5 & 2.8 & 3.0 & 3.1 \\
\hline Real domestic demand & 6.3 & 10.5 & 15.1 & 0.8 & -8.0 & -2.2 & 1.2 & 1.8 & 1.9 \\
\hline Private consumption & 5.9 & 7.2 & 11.9 & 2.3 & -5.0 & -2.0 & 1.0 & 1.8 & 2.0 \\
\hline Public consumption & 1.6 & 2.9 & 3.2 & 2.5 & 2.5 & 2.5 & 2.5 & 2.5 & 2.5 \\
\hline Fixed investment & 16.3 & 29.1 & 34.5 & -3.5 & -23.4 & -8.0 & 0.0 & 1.0 & 1.0 \\
\hline Change in stocks $1 /$ & -0.3 & 0.1 & 0.1 & 0.0 & 0.0 & 0.0 & 0.0 & 0.0 & 0.0 \\
\hline Net exports 1/ & -3.2 & -2.5 & -10.2 & 3.1 & 9.9 & 4.7 & 1.7 & 1.3 & 1.3 \\
\hline Exports & 1.6 & 8.4 & 3.5 & 7.0 & 13.9 & 10.7 & 3.9 & 3.0 & 3.0 \\
\hline Imports & 10.8 & 14.4 & 28.4 & -1.3 & -10.3 & -0.7 & 0.2 & 0.2 & 0.3 \\
\hline Current account 2/ & -5.0 & -10.1 & -16.5 & -12.5 & -4.4 & -2.5 & -3.2 & -4.1 & -3.7 \\
\hline \multicolumn{10}{|l|}{ Inflation } \\
\hline Consumer Prices & 2.1 & 3.2 & 4.0 & 6.1 & 4.5 & 3.0 & 2.5 & 2.5 & 2.5 \\
\hline \multicolumn{10}{|l|}{ Labor market } \\
\hline Employment & -0.5 & 1.3 & 1.9 & 2.0 & 0.2 & 0.4 & 0.7 & 2.0 & 2.0 \\
\hline Average unemployment rate & 3.4 & 3.1 & 2.1 & 1.5 & 1.9 & 2.3 & 2.5 & 2.5 & 2.5 \\
\hline \multicolumn{10}{|l|}{ Public finance } \\
\hline General government balance 2/ & -2.0 & 0.3 & 3.2 & 2.1 & -0.8 & -1.9 & -1.9 & -1.5 & -0.9 \\
\hline General government structural balance 2/ & -0.7 & -0.8 & 1.1 & 0.3 & -0.5 & -0.6 & -1.2 & -1.3 & -0.9 \\
\hline General government gross debt $2 /$ & 40.6 & 35.0 & 27.0 & 23.3 & 23.1 & 24.2 & 25.3 & 25.9 & 25.4 \\
\hline Output gap 3/ & -2.6 & 2.1 & 4.3 & 3.8 & -0.6 & -2.8 & -1.4 & -0.5 & 0.0 \\
\hline
\end{tabular}

Sources: $\mathrm{CBI}$; and IMF staff estimates.

1/ Contributions to growth

2/ In percent of GDP

$3 /$ In percent of potential output 


\section{Appendix I: Iceland: Fund Relations}

(As of May 31, 2006)

I. Membership Status: Joined: December 27, 1945; Article VIII

II. General Resources Account:

Quota

SDR Million

117.60

99.01

Fund holdings of currency

18.59

$$
\begin{gathered}
\text { \% Quota } \\
100.00 \\
84.20
\end{gathered}
$$

Reserve position in Fund

Holdings Exchange Rate

III. SDR Department:

Net cumulative allocation

SDR Million

\% Allocation

16.41

100.00

Holdings

0.06

0.38

IV. Outstanding Purchases and Loans: None

V. Financial Arrangements: None

VI. Projected Payments to the Fund

(SDR Million; based on existing use of resources and present holdings of SDRs):

Principal

\begin{tabular}{lllll}
\multicolumn{5}{c}{ Forthcoming } \\
\hline$\underline{2006}$ & $\underline{2007}$ & $\underline{2008}$ & $\underline{2009}$ & $\underline{2010}$
\end{tabular}

Charges/Interest

$\underline{0.30} \quad \underline{0.59} \underline{\underline{0.59}}$

$\underline{0.59}$

$\underline{0.59}$

$\underline{0.59}$

Total$$
\underline{0.59}
$$

$\underline{0.59}$

$\underline{0.59}$

VII. Implementation of HIPC Initiative: Not applicable

VIII. Exchange Rate Arrangements: Iceland adopted a floating exchange rate regime for the kröna effective March 28, 2001 and since that time the exchange rate has been determined solely by market forces.

Iceland continues to maintain exchange restrictions pursuant to $\mathrm{UN}$ sanction against Iraq (see EBD/90/242, 7/13/90).

\section{Last Article IV Consultation :}

Discussion for the 2005 Article IV Consultation were held in Reykjavik during June 2-13. 2005. The Staff Report (Country Report No. 05/367) was considered by the Executive Board on October 3, 2005. Article IV consultations with Iceland are currently held on the 12-month cycle.

X. Technical Assistance: None

XI. Resident Representative: None 


\section{Appendix II: Iceland: External Debt Sustainability}

Significant current account deficit, driven by the investment projects coupled with expansion of Icelandic firms and commercial banks abroad, resulted in a sharp increase of the external debt (from 143.0 percent of GDP in 2003 to 291.3 in 2005). In net term the level of debt has risen by about 60 percentage points to 158.1 percent of GDP in 2005. As Table A1 indicates, in the baseline scenario external debt is projected to stabilize just below 150 percent of GDP. The alternative scenarios and bound tests indicate that while various shocks could drive the net external debt to up to 165 percent of GDP, an additional 30 percent depreciation in real terms could push the level of net external debt to 250 percent of GDP. It should be noted however, that the baseline scenario already assumes 15 percent depreciation in nominal terms in 2006 . 
Table 1. Iceland: External Debt Sustainability Framework, 2000-10

(In percent of GDP, unless otherwise indicated)

\begin{tabular}{|c|c|c|c|c|c|c|c|c|c|c|c|c|}
\hline & \multicolumn{5}{|c|}{ Actual } & \multicolumn{7}{|c|}{ Projections } \\
\hline & 2001 & 2002 & 2003 & 2004 & 2005 & 2006 & 2007 & 2008 & 2009 & 2010 & 2011 & Debt-stabilizing \\
\hline Baseline: External debt & 102.6 & 91.3 & 95.7 & 115.5 & 158.1 & 146.9 & 148.8 & 148.2 & 148.8 & 150.0 & 149.3 & $\begin{array}{c}\text { current account 6/ } \\
12.7\end{array}$ \\
\hline Change in external debt & 8.1 & -11.3 & 4.4 & 19.7 & 42.6 & -11.1 & 1.9 & -0.6 & 0.6 & 1.1 & -0.7 & \\
\hline Identified external debt-creating flows $(4+8+9)$ & 14.4 & -9.7 & -11.1 & 5.1 & 24.8 & -3.3 & 4.5 & -1.0 & -0.5 & 0.1 & -0.3 & \\
\hline Current account deficit, excluding interest payments & -1.0 & -5.2 & 1.4 & 6.2 & 10.4 & -1.7 & -10.7 & -13.3 & -12.9 & -12.5 & -13.0 & \\
\hline Deficit in balance of goods and services & 1.0 & -1.7 & 3.0 & 5.6 & 12.8 & 7.5 & -1.0 & -3.4 & -2.8 & -2.2 & -2.7 & \\
\hline Exports & 39.1 & 38.2 & 34.8 & 34.5 & 32.2 & 38.7 & 42.0 & 43.3 & 42.1 & 40.8 & 40.5 & \\
\hline Imports & 40.1 & 36.5 & 37.8 & 40.1 & 45.0 & 46.1 & 41.0 & 39.9 & 39.2 & 38.6 & 37.8 & \\
\hline Net non-debt creating capital inflows (negative) & 0.9 & 2.1 & 1.2 & 11.8 & 28.2 & -9.5 & 1.5 & 0.3 & 0.3 & 0.4 & 0.5 & \\
\hline Automatic debt dynamics $1 /$ & 14.6 & -6.5 & -13.6 & -12.8 & -13.9 & 8.0 & 13.6 & 12.1 & 12.0 & 12.1 & 12.2 & \\
\hline Contribution from nominal interest rate & 5.4 & 3.7 & 3.6 & 3.9 & 6.1 & 14.2 & 15.1 & 15.7 & 16.1 & 16.5 & 16.7 & \\
\hline Contribution from real GDP growth & -3.9 & 1.0 & -2.2 & -6.5 & -5.3 & -6.3 & -1.5 & -3.7 & -4.1 & -4.4 & -4.5 & \\
\hline Contribution from price and exchange rate changes $2 /$ & 13.1 & -11.1 & -15.0 & -10.2 & -14.7 & $\ldots$ & $\ldots$ & $\ldots$ & $\ldots$ & $\ldots$ & $\ldots$ & \\
\hline Residual, incl. change in gross foreign assets (2-3) $3 /$ & -6.3 & -1.7 & 15.5 & 14.6 & 17.8 & -7.9 & -2.6 & 0.4 & 1.2 & 1.0 & -0.3 & \\
\hline External debt-to-exports ratio (in percent) & 262.2 & 239.0 & 275.0 & 334.7 & 491.1 & 380.0 & 354.3 & 342.4 & 353.8 & 367.4 & 368.8 & \\
\hline Gross external financing need (in billions of US dollars) $4 /$ & 3.6 & 3.4 & 5.1 & 7.7 & 10.4 & 12.8 & 11.3 & 11.2 & 11.4 & 11.7 & 11.9 & \\
\hline in percent of GDP & 45.5 & 38.3 & 47.3 & 59.0 & 65.6 & 79.6 & 69.5 & 67.7 & 68.2 & 69.0 & 68.2 & \\
\hline Scenario with key variables at their historical averages 5 / & & & & & & 146.9 & 147.3 & 148.3 & 149.8 & 151.1 & 153.1 & 0.0 \\
\hline \multicolumn{13}{|l|}{ Key Macroeconomic Assumptions Underlying Baseline } \\
\hline Real GDP growth (in percent) & 3.8 & -1.0 & 3.0 & 8.2 & 5.5 & 4.0 & 1.0 & 2.5 & 2.8 & 3.0 & 3.1 & \\
\hline GDP deflator in US dollars (change in percent) & -12.2 & 12.2 & 19.6 & 11.9 & 14.6 & -2.3 & 0.3 & -1.3 & -1.5 & -1.5 & 0.0 & \\
\hline Nominal external interest rate (in percent) & 5.2 & 3.9 & 4.8 & 4.9 & 6.4 & 9.2 & 10.4 & 10.7 & 11.0 & 11.3 & 11.5 & \\
\hline Growth of exports (US dollar terms, in percent) & 5.5 & 8.3 & 12.3 & 20.0 & 12.8 & 22.1 & 10.1 & 4.3 & -1.6 & -1.6 & 2.2 & \\
\hline Growth of imports (US dollar terms, in percent) & -11.0 & 1.1 & 27.6 & 28.2 & 35.8 & 4.3 & -10.0 & -1.4 & -0.4 & -0.2 & 0.8 & \\
\hline Current account balance, excluding interest payments & 1.0 & 5.2 & -1.4 & -6.2 & -10.4 & 1.7 & 10.7 & 13.3 & 12.9 & 12.5 & 13.0 & \\
\hline Net non-debt creating capital inflows & -0.9 & -2.1 & -1.2 & -11.8 & -28.2 & 9.5 & -1.5 & -0.3 & -0.3 & -0.4 & -0.5 & \\
\hline
\end{tabular}

$1 /$ Derived as $[\mathrm{r}-\mathrm{g}-\rho(1+\mathrm{g})+\varepsilon \alpha(1+\mathrm{r})] /(1+\mathrm{g}+\rho+\mathrm{g} \rho)$ times previous period debt stock, with $\mathrm{r}=$ nominal effective interest rate on external debt; $\rho=$ change in domestic GDP deflator in US dollar terms, $\mathrm{g}=$ real GDP growth rate,

$\varepsilon=$ nominal appreciation (increase in dollar value of domestic currency), and $\alpha=$ share of domestic-currency denominated debt in total external debt.

$2 /$ The contribution from price and exchange rate changes is defined as $[-\rho(1+\mathrm{g})+\varepsilon \alpha(1+\mathrm{r})](1+\mathrm{g}+\rho+\mathrm{g} \rho)$ times previous period debt stock. $\rho$ increases with an appreciating domestic currency $(\varepsilon>0)$ and rising inflation (based on GDP deflator).

3/ For projection, line includes the impact of price and exchange rate changes.

4/ Defined as current account deficit, plus amortization on medium- and long-term debt, plus short-term debt at end of previous period.

5/ The key variables include real GDP growth; nominal interest rate; dollar deflator growth; and both non-interest current account and non-debt inflows in percent of GDP.

6/ Long-run, constant balance that stabilizes the debt ratio assuming that key variables (real GDP growth, nominal interest rate, dollar deflator growth, and non-debt inflows in percent of GDP) remain at their levels

of the last projection year. 
Figure 1. Iceland: External Debt Sustainability: Bound Tests 1/ (External debt in percent of GDP)
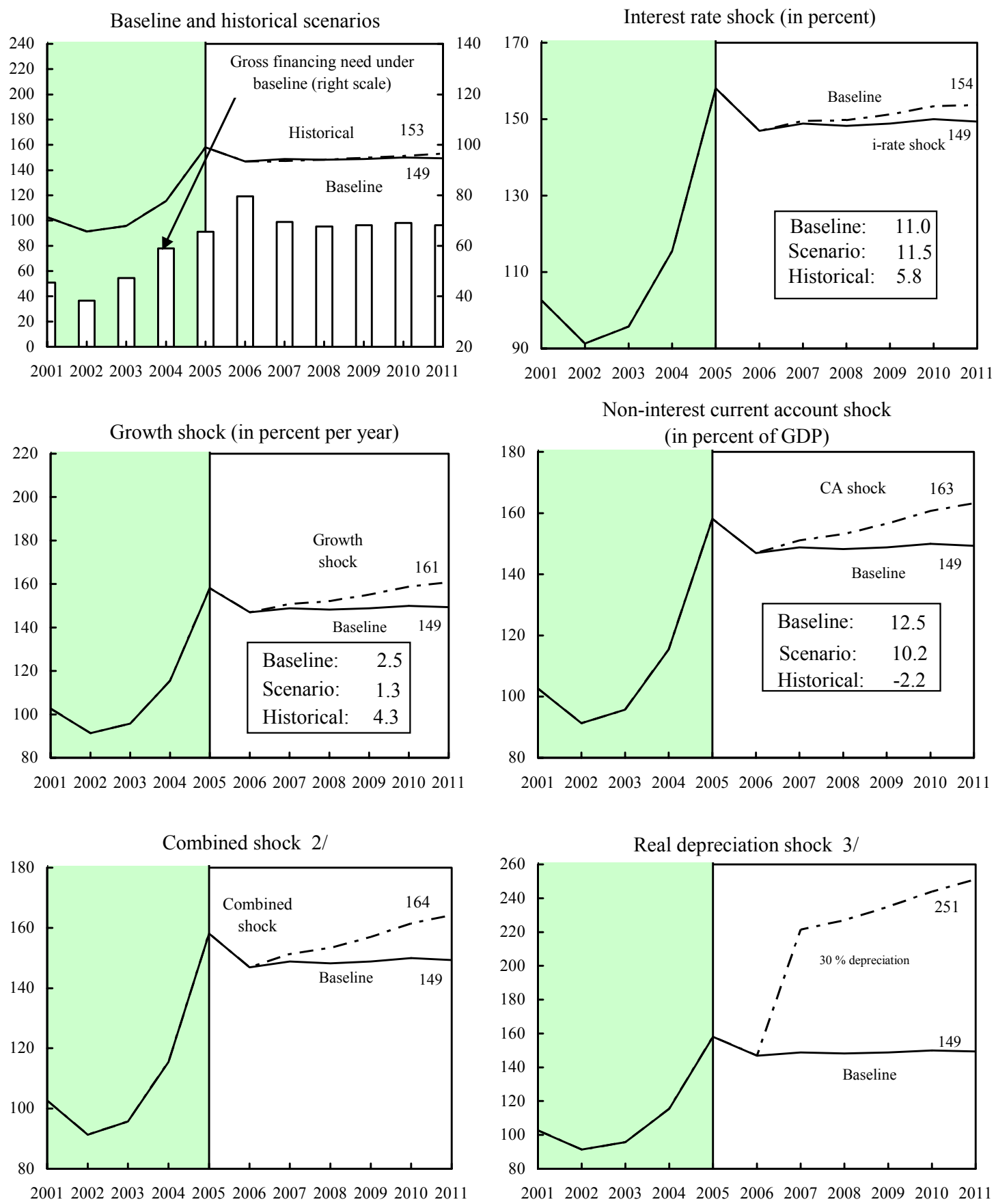

Sources: International Monetary Fund, Country desk data, and staff estimates.

1/ Shaded areas represent actual data. Individual shocks are permanent one-half standard deviation shocks. Figures in the boxes represent average projections for the respective variables in the baseline and scenario being presented. Ten-year historical average for the variable is also shown.

2/ Permanent 1/4 standard deviation shocks applied to real interest rate, growth rate, and current account balance.

3/ One-time real depreciation of 30 percent occurs in 2006 . 


\section{Statement by the IMF Staff Representative August 4, 2006}

1. This statement provides an update on developments in Iceland since the circulation of the staff report to the Board. The new information does not change the thrust of the staff appraisal, but developments in the external accounts and inflation heighten the risks and strengthen the case for a more restrictive fiscal stance.

2. Iceland's external imbalance continues to widen and inflation has accelerated further. In 2006Q1, imports grew by 17.5 percent while exports shrunk by 7.5 percent, doubling the current account deficit with respect to a year earlier. Monthly trade data suggest that this trend continued in the second quarter with June's trade deficit reaching a record level. Annual CPI inflation reached 8.4 percent in July, while wages posted 8.8 percent year-on-year growth in June. However, the housing market, which had been a key driver of inflation, has started to cool. Reykjavik's housing price index rose by 0.6 percent in June bringing the 3-month rate of change down to 1.6 percent from 4.3 percent the previous three months.

3. The Central Bank responded by raising its policy rate. The policy interest rate was increased by 75 basis points to 13 percent on July 6 and an additional policy setting meeting has been announced for August 16. Market participants expect the policy rate to rise following the meeting and possibly reach 14.5 percent by the end of the year. Exchange rate movements since the issuance of the staff report have been more contained: as of August 2, the ISK nominal effective exchange rate index had appreciated by slightly under 3 percent relative to the last observation of June 12 presented in the staff report.

4. The government has announced planned measures to reduce demand pressures in the economy. The maximum loan-to-value ratio on loans issued by the Housing Finance Fund (HFF) has been temporarily decreased from 90 to 80 percent and the HFF's loan limits have been temporarily reduced from ISK 18 to 17 million. Tenders and commencement of new central government investment projects will be postponed and discussions are underway with local governments to reduce investment this year and next. Some local governments have announced plans to do so. This is being done against the background of an improving fiscal position. In the first quarter of 2006, the general government financial balance rose to a surplus of 1.5 percent of annual GDP (against 0.7 percent a year ago).

5. The Government, trade unions, and the employers' confederation reached a consensus to maintain the current wage agreement which could have been canceled in November 2006 owing to high inflation. To maintain the current wage agreement, the government has committed to increase the tax-free income threshold by 14 percent starting in 2007, index this threshold to inflation thereafter, and increase the minimum wage by 15.7 percent. To finance these changes, the reduction in the income tax rate set to occur in January 2007 has been reduced to 1 percentage point rather than the previously planned 2 percentage points. 
6. Second quarter bank results suggest that profitability remains strong despite losses on equity holdings. Net earnings of Kaupthing Bank and Landsbanki declined in the second quarter compared to the first (by 57 and 35 percent correspondingly), while those of Glitnir increased by 21 percent. However, all the banks reported that their net profits for the first six months of 2006 have grown relative to the same period a year ago, although to a different degree (26 percent for Kaupthing Bank, 84 percent for Landsbanki, and 91 for Glitnir). 


\section{IMF Executive Board Concludes 2006 Article IV Consultation with Iceland}

On August 4, 2006, the Executive Board of the International Monetary Fund (IMF) concluded the Article IV consultation with Iceland. ${ }^{1}$

\section{Background}

Driven by an expansion of the aluminum sector, Iceland is going through an economic boom that is generating large imbalances. Strong domestic demand, reflecting rapidly growing investment and private consumption, is overheating the economy and leading to high inflation and record current account deficits. As global monetary policy tightened early in the year, volatility in Icelandic financial markets increased as international investors became concerned about the risks associated with macroeconomic imbalances and potential vulnerabilities in the financial sector.

Following a recession in 2002, economic growth accelerated sharply reaching 8.2 percent in 2004 , slowing only modestly to 5.5 percent in 2005 . Pre-announced income tax cuts, an appreciated exchange rate, and an easing in household credit constraints stimulated private consumption. With investment also growing rapidly due to the aluminum sector projects, domestic demand posted growth of 10.5 percent in 2004 and 15.1 percent in 2005. As domestic demand gathered speed, the trade deficit more than doubled, reaching 12.8 percent of GDP in 2005 and the current account deficit hit 16.5 percent of GDP. Meanwhile inflation rose to 8.4 percent year-on-year in June 2006 , well above the 4 percent upper bound of Central Bank's tolerance range.

\footnotetext{
${ }^{1}$ Under Article IV of the IMF's Articles of Agreement, the IMF holds bilateral discussions with members, usually every year. A staff team visits the country, collects economic and financial information, and discusses with officials the country's economic developments and policies. On return to headquarters, the staff prepares a report, which forms the basis for discussion by the Executive Board. At the conclusion of the discussion, the Managing Director, as Chairman of the Board, summarizes the views of Executive Directors, and this summary is transmitted to the country's authorities. This PIN summarizes the views of the Executive Board as expressed during the August 4, 2006 Executive Board discussion based on the staff report.
} 
Monetary authorities responded to growing demand pressures by raising interest rates to 13 percent in July 2006 from 5.3 percent in May 2004. However, until recently, the monetary tightening impacted economy primarily through an appreciated exchange rate because the increased competition between the state-owned Housing Finance Fund (HFF) and commercial banks lowered long-term mortgage rates and increased the availability of household credit. The fiscal stance also tightened with the general government balance moving to a surplus of 3.2 percent of GDP in 2005 from a deficit of 2.0 percent of GDP in 2003.

In the first half of 2006, a series of negative reports by analysts and rating agents increased international investors' concerns about the consequences of Iceland's macroeconomic imbalances. As global monetary conditions tightened, investor concerns lead to an unwinding of carry-trade positions, putting downward pressure on the exchange rate and equity prices, as well as widening credit spreads for Icelandic banks whose balance sheets had been expanding rapidly.

GDP is forecast to grow by 4.0 percent in 2006 , reflecting completion of the investment projects and continued strong private consumption. However, as investment returns to normal levels and consumption weakens due to currency depreciation and tighter credit conditions, growth is projected to fall to 1.0 percent in 2007 . Inflationary pressures are expected to persist and further tightening of monetary policy is likely. The fiscal surplus is projected to decline slightly, although steps, undertaken mid year, to postpone additional public investment projects should improve the fiscal balance relative to that previously expected as well as help ease demand pressures. The current account deficit is forecast to remain high in 2006 (12.5 percent of GDP) and then improve sharply in 2007 (4.4 percent of GDP) as growth rebalances toward the export sector reflecting, in part, increased aluminum-sector capacity and a more competitive exchange rate.

\section{Executive Board Assessment}

The Executive Directors noted that, while medium-term prospects are favorable, large and growing imbalances, evidenced by current account and inflation developments, pose risks to real growth and financial stability in the short term. Thus, Directors welcomed measures taken to curb demand pressures, including those recently announced, but they called for further decisive policy actions to stabilize confidence, help ensure an orderly adjustment, and maintain financial stability.

Directors emphasized that, despite low and declining public debt, further fiscal restraint, beyond current plans, is essential to reducing imbalances and averting their associated risks. The required fiscal tightening could be achieved by some combination of postponing additional public investment projects and reducing growth in public consumption expenditure. Looking ahead, Directors stressed that there is a strong case for considering further restraint in the budget for 2007 if domestic demand pressures do not abate as required.

Directors called for a further strengthening of the medium-term fiscal framework to help reduce volatility in the Icelandic economy. They observed that the introduction of multi-year budgeting was the first step along the path to a rules-based multi-year framework. Adding more structure to the budgeting and implementation processes will ensure a consistently countercyclical fiscal stance that would reinforce monetary policy and thereby increase economic stability. 
Directors agreed that further increases in the monetary policy rate would likely be required to anchor expectations and return inflation to target. With additional inflationary pressures expected from currency depreciation, and tight goods and labor markets, real interest rates needed to rise. In

this context, Directors viewed the recent rate increases as appropriate and welcomed the early signs that monetary policy is starting to have more of an impact on credit conditions faced by households and firms. The recent consensus reached by the social partners to maintain the current wage agreement should also help reduce uncertainty. This notwithstanding, given the high output cost of returning inflation to target should inflationary expectations become entrenched, Directors concurred that monetary policy should be biased toward a tight stance.

Directors noted that the flexible exchange rate regime in the context of the inflation-targeting monetary policy framework has served Iceland well. Although the year-to-date depreciation of the krona occurred sooner and faster than expected, Directors generally viewed the depreciation in the currency as an appropriate adjustment toward its equilibrium value.

Directors stressed the importance of actions directed at reducing vulnerabilities in the financial sector. Despite the strong balance sheets of financial institutions, the banks' rapid expansion has increased their risk profile. Directors welcomed the steps banks have taken so far to make these risks more manageable. Nevertheless, they stressed that the process needs to continue, with the encouragement and close monitoring of the supervisory authorities.

Directors welcomed the strengthening of the supervisory and financial stability frameworks. They commended the Financial Supervisory Authority (FME) for quickly implementing broader and more stringent stress tests, which should provide positive assurance to the markets.

Directors recommended an immediate reform of the Housing Finance Fund. They noted that the increased competition in the mortgage market between the banks and the state-owned Housing Finance Fund had undermined the effectiveness of monetary policy, exacerbated excess demand, and increased the risks to financial stability. Following international experiences, Directors encouraged the authorities to consider a new privately-held wholesale funding institution that would retain the positive features of the current system as well as allow for healthy competition in the mortgage market.

Public Information Notices (PINs) form part of the IMF's efforts to promote transparency of the IMF's views and analysis of economic developments and policies. With the consent of the country (or countries) concerned, PINs are issued after Executive Board discussions of Article IV consultations with member countries, of its surveillance of developments at the regional level, of post-program monitoring, and of ex post assessments of member countries with longer-term program engagements. PINs are also issued after Executive Board discussions of general policy matters, unless otherwise decided by the Executive Board in a particular case. The Staff Report for the 2006 Article IV Consultation with Iceland is also available. 
Real Economy (change in percent)

Real GDP

$-1.0$

3.0

8.2

5.5

4.0

Domestic demand

$-3.3$

6.3

10.5

15.1

0.8

$\mathrm{CPI}$

4.8

2.1

3.2

4.0

6.1

Unemployment rate (in percent of labor force)

2.5

3.4

3.1

2.1

1.5

Gross domestic investment (in percent of GDP)

17.4

19.7

23.4

26.3

General Government Finances (in percent of GDP)

Financial balance 2/

$\begin{array}{rrrrr}-0.8 & -2.0 & 0.3 & 3.2 & 2.1 \\ 0.5 & -0.7 & -0.8 & 1.1 & 0.3 \\ 42.6 & 40.6 & 35.0 & 27.0 & 23.3\end{array}$

Gross debt

alance

Money and Credit (change in percent)

Deposit money bank credit (end of period)

Domestic credit (end of period)

Broad money (end of period)

$\mathrm{CBI}$ policy rate (period average, in percent)

$\begin{array}{rrrr}5.2 & 22.8 & 43.0 & 65.8 \\ 0.8 & 14.8 & 39.5 & 49.3 \\ 15.3 & 17.5 & 15.0 & 23.6 \\ 8.4 & 5.4 & 6.1 & 9.4\end{array}$

Balance of Payments (in percent of GDP)

Trade balance

$\begin{array}{lllll}1.8 & -1.9 & -4.0 & -9.3 & -5.1\end{array}$

Current account balance

Financial and capital account balance

$1.6-5.0$

$-10.1$

$-16.5$

$-12.5$

$-1.1$

2.0

13.7

11.9

12.5

Gross external debt

113.1

143.0

181.9

291.3

277.7

Reserves 3/

1.5

2.3

2.2

2.0

Fund position (as of May 31, 2006)

Holdings of currency (in percent of quota)

Holdings of SDRs (in percent of allocation)

Quota (in millions of SDRs)

\section{Exchange rate}

Exchange rate regime

Present rate (July 13, 2006) 4/

Nominal effective rate (change in percent)

Real effective (change in percent)

3.0

Floating Exchange Rate

119.5

5.7

6.4

2.1

11.4

6.3

3.3

10.0

Sources: Statistics Iceland, Central Bank of Iceland, Ministry of Finance, and IMF staff estimates.

1/ Projection.

2/ National accounts basis.

$3 /$ In months of imports of goods and services.

4/ Trade weighted index of the exchange rate as kronur per unit of foreign currency $(12 / 31 / 1991=100)$ 